\title{
Geological, geochemical and fluid inclusion investigations on the Duna Pb-Ba-(Ag) deposit, Central Alborz, North Central Iran
}

\author{
Alireza Sadeghi ${ }^{1}$, Nima Nezafati2*, Saeid Hakimi-Asiabar ${ }^{3}$ and Alireza Ganji ${ }^{4}$ \\ ${ }^{1}$ Islamic Azad University, Science and Research Branch, Department of Earth Sciences, Tehran, Iran; (asadeghi.1345@gmail.com) \\ 2 Department of Earth Sciences, Islamic Azad University, Science and Research Branch, Tehran, Iran; German Mining Museum, Department of Archaeometallurgy, \\ Bochum, Germany (*corresponding author; nima.nezafati@gmail.com, nima.nezafati@bergbaumuseum.de) \\ ${ }^{3}$ Islamic Azad University, Lahijan Branch, Department of Geology, Lahijan, Iran; (saeid.h.asiabar@gmail.com) \\ ${ }^{4}$ Islamic Azad University, Lahijan Branch, Department of Geology, Lahijan, Iran; (ar_ganji2000@yahoo.com)
}

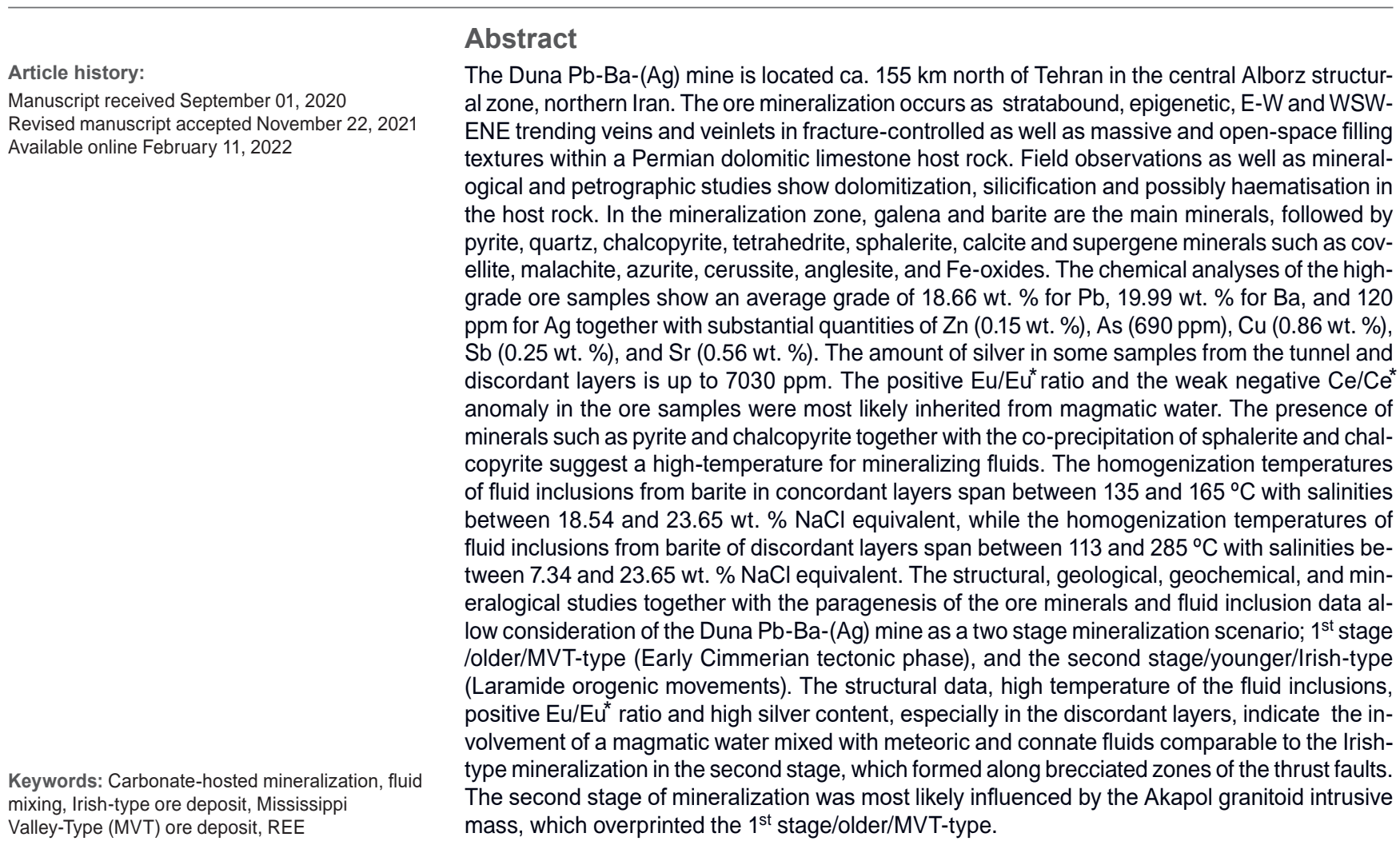

\section{INTRODUCTION}

The Alborz mountain range with a general E-W trend, $1000 \mathrm{~km}$ length and a width of 50 to more than $100 \mathrm{~km}$ between the Caspian Sea and the Iranian Plateau resulted from the collision of the Iran and Turan plates (Fig. 1b) in the Late Triassic in northern Iran (AGHANABATI, 2004). The Alborz zone was affected by several successive tectonic events, including the Early Cimmerian orogeny in the lower Triassic to Cretaceous-Tertiary compression event (ALLEN et al., 2003; GOLONKA, 2004; GUEST et al., 2006; HORTON et al., 2008; ZANCHI et al., 2009; MIRNEJAD et al., 2015 ). Folding and thrusting of Palaeozoic to Mesozoic sedimentary sequences in the Alborz host a variety of $\mathrm{Pb}$ and $\mathrm{Zn}$ deposits such as the middle Permian limestone (Ruteh Formation), Lower-Middle Triassic dolomite and Middle-Late Triassic Limestone (Elika Formation), Jurassic limestone (Lar and Dalichai Formations), and Cretaceous limestone and dolomite (MIRNEJAD et al., 2015). Metals were thought to have been sourced from the Upper Palaeozoic rock units of the Alborz range (HOLZER \& MOMENZADEH, 1969; SAMANIRAD, 1999).
Previous studies of model $\mathrm{Pb}$ isotopes and plumbotectonics (ZARTMAN \& DOE, 1981) show that most of the Pb-Zn deposits in the Alborz and Central Iran were in contact with mantle and crust and the $\mathrm{Pb}$ isotopic ratios of galena mineralization in the Duna mine are similar to the $\mathrm{Pb}-\mathrm{Zn}$ deposits of the UrumiehDokhtar volcanic belt and are related to the Cenozoic magmatic activity (HASSANZADEH et al., 2002). The Alborz Zone is principally a sedimentary zone with some magmatic features, where sedimentary units from Late Precambrian to Neogene ages are exposed (AGHANABATI, 2004).

Based on the geological investigations, the Alborz zone is one of the most promising areas for lead and zinc mineralization in Iran. Containing more lead than zinc and more lead minerals than other sulfide minerals, being hosted by Permian to Tertiary rocks mostly of carbonaceous origin (especially in the Ruteh Carbonate Formation of Permian age), being mostly surrounded by volcanic rocks, tuff, and intrusive masses, and having low copper and in most cases high silver contents are among the features that characterize the Pb-Zn deposits of central Alborz (GHORBANI, 2013). 


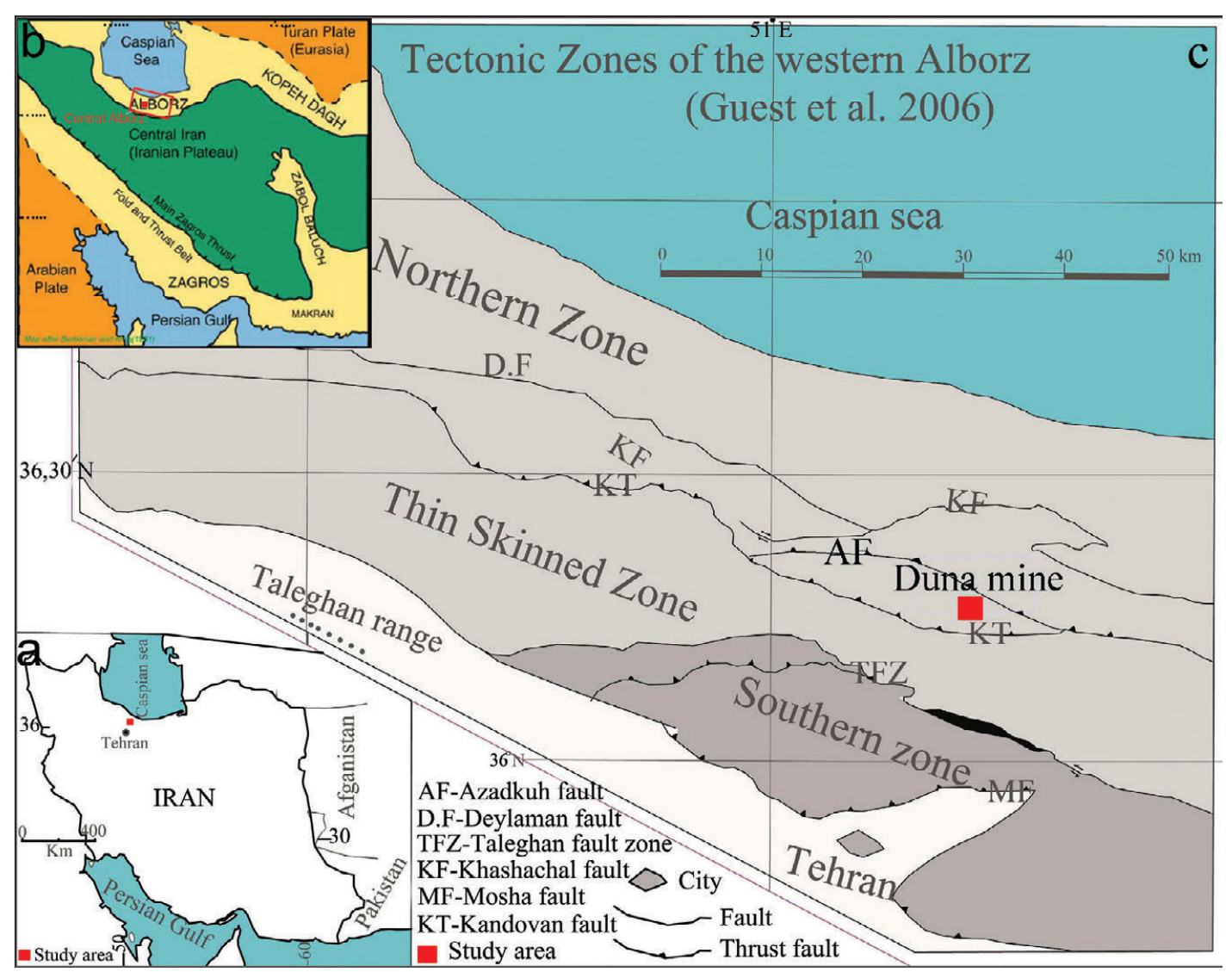

Figure 1. a , c) Location of the Duna mine in the central Alborz structural zone (modified after GUEST et al., 2006). b) Simplified structural unit of Iran with the Arabian Plate in the south and the Turan Plate in the north (after BERBERIAN \& KING, 1981).

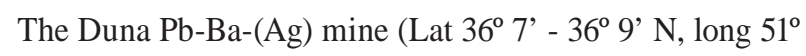
$20^{\prime}-51^{\circ} 25^{\prime} \mathrm{E}$ ), with probable ore reserves of 0.5 to $1 \mathrm{Mt} @ 6.7 \%$ $\mathrm{Pb}$ and $1400 \mathrm{ppm}$ Ag (GHORBANI, 2013), is one of the most complex deposits of the Alborz tectonic zone, which is situated in northern Tehran province, about $155 \mathrm{~km}$ north of Tehran, Iran (Fig. 1a).

Lead and zinc usually occur here as sulfide minerals; mainly galena and sphalerite in three major types of VMS, SEDEX, and MVT deposits, as well as in distal skarn deposits, intermediatetype epithermal deposits, etc. (DAVIDHEISER-KROLL, 2014). There are different beliefs regarding Irish-type dependency and similarity to SEDEX and MVT deposits. Mississippi Valley-type (MVT) deposits are epigenetic, stratabound, carbonate-hosted sulphide bodies, composed predominantly of zinc and lead, bound in sphalerite and galena (PARADIS et al., 2007) and some Irish-type deposits are sub-types of MVT deposits (HITZMAN \& BEATY, 1997). They are located in carbonate platform settings, typically in relatively undeformed orogenic foreland rocks, commonly in foreland thrust belts, and rarely in rift zones (LEACH \& SANGSTER, 1993). The Irish-type deposits are stratabound, structurally controlled, carbonate-hosted, $\mathrm{Pb}-\mathrm{Zn}$ deposits that have sedimentary exhalative (SEDEX) and/or MVT characteristics (HITZMAN \& BEATY, 1997). Irish-type deposits are considered to have been formed by ore-forming processes similar to those of SEDEX deposits but, because carbonate platforms are highly soluble in mildly acidic ore fluids, ores were also deposited in the hydrothermal karst system (e.g. dissolution voids, collapse breccias) (GOODFELLOW \& LYDON, 2007). In case of the Duna mine, Holzer and Momenzadeh (1969) consider this mineralization as an example related to the Permian volcanogenic origin in Central Alborz.

In the present study, geochemistry of the major and the rare earth elements (of the ore, barite, host and igneous rock), mineralogy, and fluid inclusion studies as well as structural geology together with the review of previous studies were used to determine the genetic model and the type of mineralization in the Duna mine. These also resulted in better understanding of the role of plutonic bodies in the mineralization, the source of mineralizing fluids, and the role of some specific fault sets (rather than others) in the mineralization of the Duna mine.

\section{GEOLOGICAL SETTING}

The Central Alborz zone runs from west to east along the southern coast of the Caspian Sea (Alavi 1991). The Duna Pb-Ba-(Ag) mine is located in the Central Alborz zone and between two major faults with a general E-W trend, including the Kandovan Thrust Fault with a length of about $100 \mathrm{~km}$ in the south and the Azadkuh Fault with a length of about $30 \mathrm{~km}$ in the north (Fig. 1c). The distance between Kandovan and Azadkuh Faults from the Duna mine is less than 1000 and 300 metres, respectively. Guest et al. (2006) have divided the Central Alborz into the northern Alborz zone, thin-skinned zone, southern zone, and the Taleghan range (Fig. 1c).

In the Northern zone, deformation intensifies presumably southward- from the northern foothills to the range crest. This zone is composed of W-E striking faults and folds. The northern zone was deformed during the Laramide orogeny (HAKIMI ASIABAR \& BAGHERIAN, 2018). The Duna mine is located in the thin-skinned zone, confined between the Azadkuh and Kandovan 


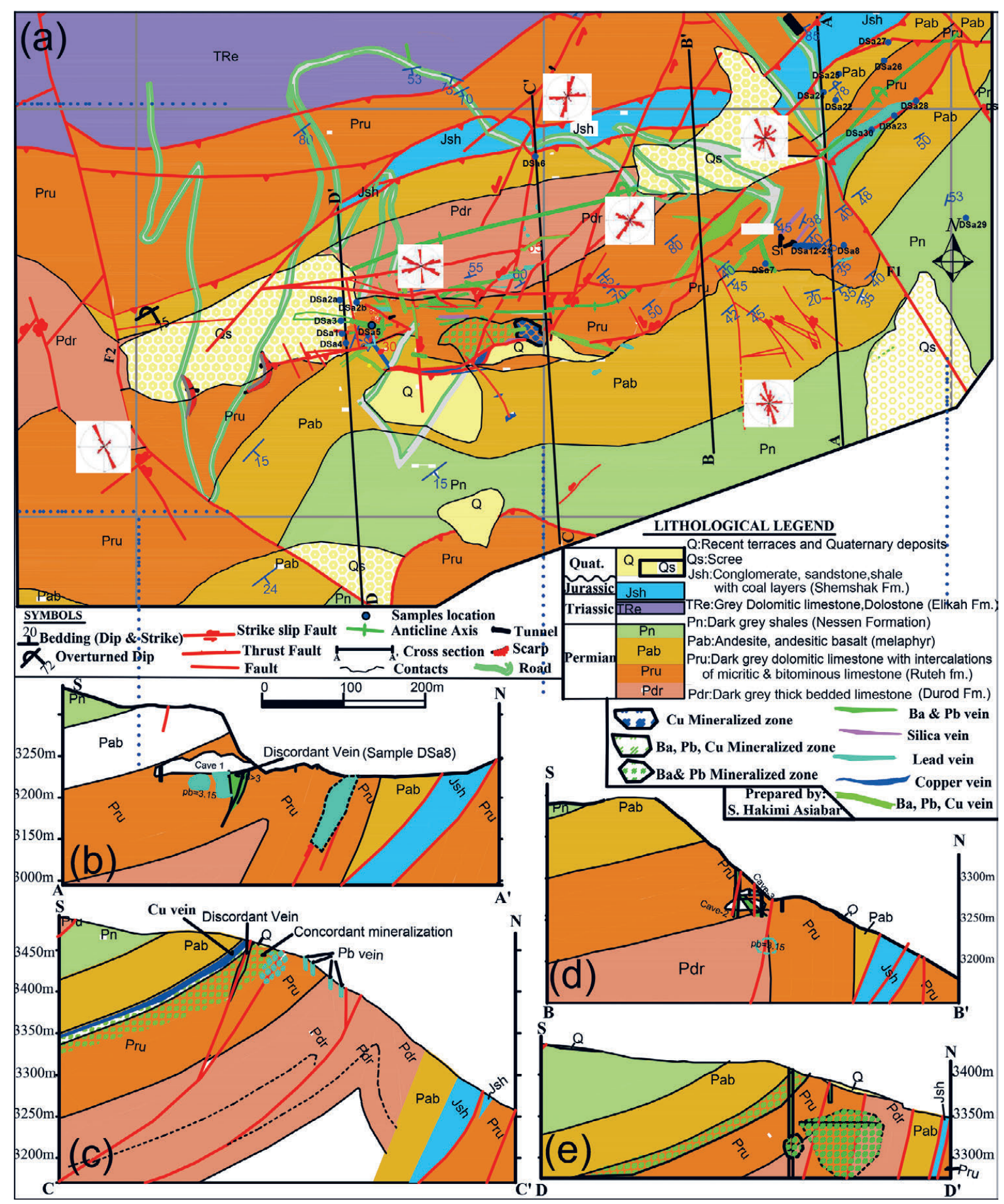

Figure 2. A geological map of the Duna mine (HAKIMI ASIABAR, 2019). A-A' and B-B' sections from tunnel (second stage/younger/lrish-type) and D-D' Section from open pit (mostly $1^{\text {st }}$ stage/older/MVT).

Faults. The thin-skinned zone shows strong evidence of Late Miocene deformation. The thrust faults of the thin-skinned zone generally strike northwest-southeast, whereas the Late Miocene microdiorite dyke swarm that intrudes into the thin-skinned zone cuts across but is slightly offset by the thrusts, and strikes northeast-southwest (GUEST et al., 2006). The Southern zone comprises NW-SE trending thrusts, synclines, and anticlines, which were refolded, and formed an older set of folds that trend roughly NE-SW (GUEST et al., 2006). Most of the Taleghan range is composed of a large, open, upright, gently west-plunging anticline with its limbs truncated by the high-angle Taleghan Fault zone, along with its northern flank, and by the Mosha thrust, along with its southern flank (GUEST et al., 2006).

The Duna carbonate-hosted lead mine is situated in an anticline and is part of an uplift (or pop-up) tectonic structure with an asymmetric rhombus shape (MCCLAY \& BONORA, 2000) that was formed by reverse tectonic movements and performance of the Kandovan and Azadkuh faults.

The Duna anticline structure consists of Palaeozoic to Quaternary rocks (Fig. 2). The Palaeozoic units are composed of sandstone, siltstone, and red shale of Lower Permian rocks (Dorud formation - Pdr) as well as the dolomitic limestone of the 
Table 1. The ICP-MS analysis results of the Duna mine samples in ppm (Ore, HR: Host Rock, IR: Igneous Rock, Brt: Barite). dis: discordant veins (mostly second stage/ younger/Irish-type); con: concordant veins (mostly $1^{\text {st }}$ stage/older/MVT-type); dol: dolomite; mel: melaphyre unit.

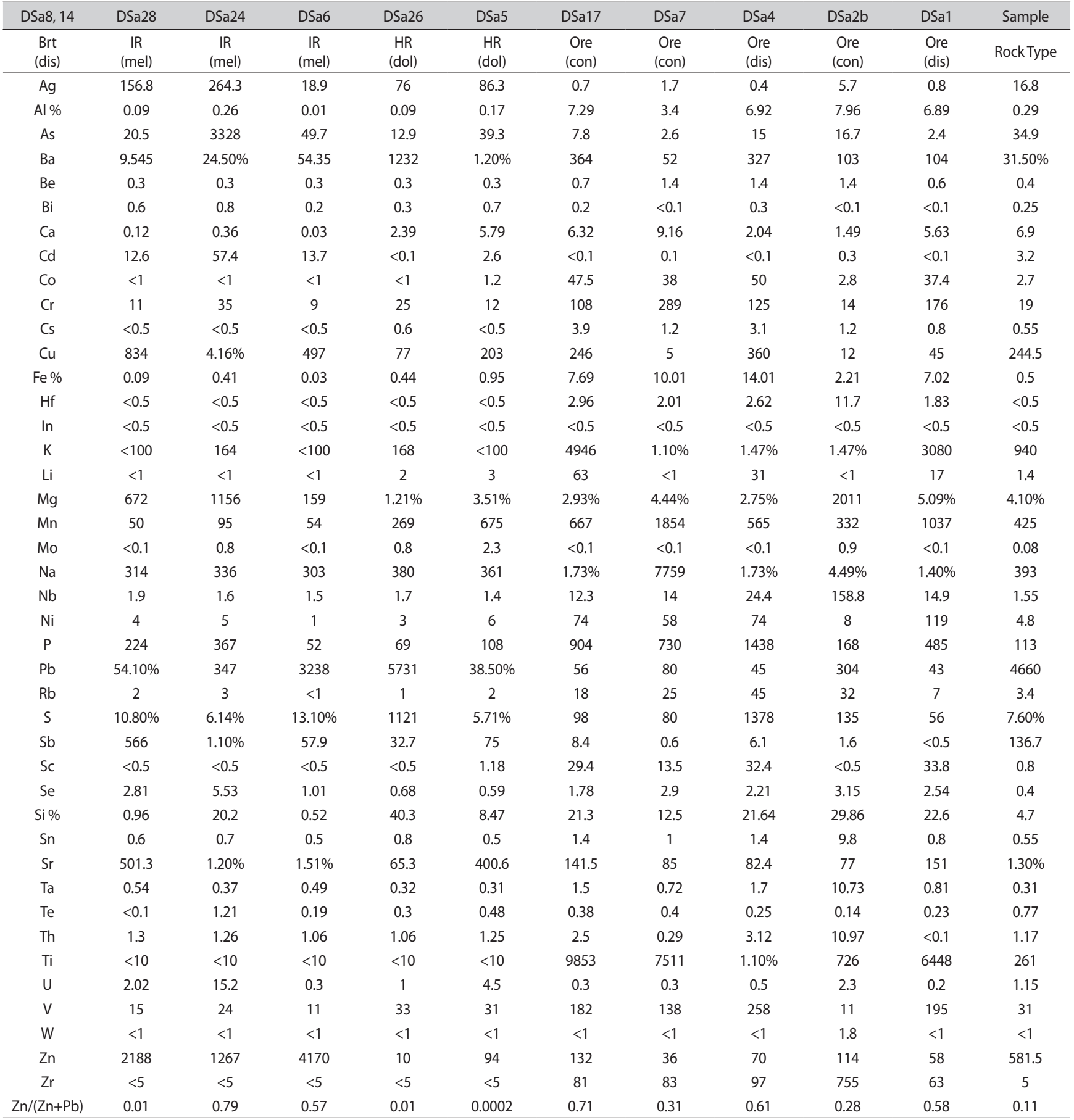

Middle Permian which is composed of layers of micritic and bituminous limestone of the Ruteh Formation (Pru). The Ruteh Formation is the main host of the mineralization in the Duna $\mathrm{Pb}$ $\mathrm{Ba}-(\mathrm{Ag})$ mine. After the sedimentation of the Ruteh Formation, the sea retreated in most parts of the Central Alborz and volcanic rocks including dolerite, olivine basalt, trachyandesite and andesibasalt (ranging from 50 to 80 metres in thickness) covered some areas (AGHANABATI, 2004). It was then that the Nessen Formation (Pn) comprising of shale and sandstone was formed in the Upper Permian. The Mesozoic rocks of the study area are composed of Lower Triassic carbonate rocks, grey dolomitic limestone, and cream dolostone of the Elika Formation (TRe) that are unconformably covered by the Late Triassic to Middle Jurassic shale, sandstone, and conglomerate of the Shemshak Forma- tion (J.Sh). The Early Cimmerian orogenic movements caused an angular unconformity between the Jurassic Shemshak and the Triassic Elika Formations in the Alborz mountain range (ANNELLS et al., 1975; ALLEN et al., 2003; BAHARFIRUZI \& SHAFEII, 2005) including the study area. During the Upper Cretaceous, deposition of the sedimentary rock units of the northern part of the study area began with benthic limestone and gradually changed into hemipelagic to pelagic sediments (MODARESNIA et al., 2012). The Late Cimmerian event has caused angular unconformities between Jurassic and Cretaceous sediments of the thin-skinned and southern folded zones of the Alborz range (ANNELLS et al., 1975; BAHARFIRUZI \& SHAFEII, 2005). Neogene sediments crop out in the intermontane basins and in the southern margin of the Duna anticline. They include conglomer- 
ates and fine clastic deposits which are mostly red in colour. This sequence lies unconformably on Palaeogene volcanic and sedimentary rock sequences. Quaternary deposits are widespread on the Caspian plain and are preserved as patches in many places including the intermontane basins. In addition to some melaphyre rocks, the Akapol intrusive mass (4 km south of Duna) and the Alamkuh intrusive body (300 metres north of the Duna mine) indicate some past magmatic activities in the area.

\section{SAMPLING AND ANALYTICAL TECHNIQUES}

Field geology and sampling were conducted in three stages on a $3 \mathrm{~km}^{2}$ area in the summer and autumn of 2017 as well as in summer 2018. Twenty-eight samples from the concordant $/ 1^{\text {st }}$ stage/ older/ MVT-type and discordant/second stage/younger/Irish-type of mineralization were selected from different parts of the Duna mine. Thirteen samples from the orebodies, three samples from the host rock, five samples from massive barite and seven samples from the igneous rocks were taken from different points and horizons. The location of these samples have been plotted on the 1:1000 geologic map (Fig. 2).

In order to determine the concentrations of trace and rare earth elements, 12 samples were collected from various locations including five samples of mineralized limestone from concordant $/ 1^{\text {st }}$ stage (Dsa7 and Dsa17) and discordant/second stage of mineralization (Dsa1, Dsa2b and Dsa4), two samples of dolomitic host rocks (DSa5, DSa26), three samples of igneous rocks (DSa6, DSa24, and DSa28), as well as two samples of massive barite (DSa8 and DSa14) from the concordant/second stage. All samples were analyzed by ICP-MS (Inductively Coupled Plasma-Mass Spectrometer) method (in ppm) at the Zarazma Mineral Studies Company, Iran (Table 1 \& Table2), using a PERKIN 9000 DRCE model, following a near-total digestion applying four acid digestion including $\mathrm{HF}, \mathrm{HCl}, \mathrm{HClO} 4$ and HNO3. The various steps of the sample preparation include drying at $120^{\circ} \mathrm{C}$, crushing to less than $4 \mathrm{~mm}$, and pulverizing to $75 \mu \mathrm{m}$ and analyzed under high temperature and multi acid digestion.

The Petrographic study was performed on 29 polished-thin sections at the mineralogical laboratory of the Science and Research Branch of the Islamic Azad University. Ore mineralogy studies were conducted on eleven sections at the mineralogical laboratory of the Geological Survey of Iran using a polarizing microscope. One ore sample from the discordant/second stage/ younger/Irish-type (code Dsa1) was selected and analyzed by the Electron Probe Micro Analysis (EPMA) method at 12 points on its tetrahedrite, galena and sphalerite minerals. Analyses were performed in the Iranian Mineral Processing Research Center (IMPRC), Karaj, Iran. The EPMA was performed for a more detailed study on the Ag and other trace elemental contents of the ore sample of Duna mine. For this purpose, a EPMA CAMECA with Sx100, accelerating voltage of $20 \mathrm{kev}$, a beam current of 20 $\mathrm{nA}$, a beam size of $5 \mu \mathrm{m}$, and a detection limit $500 \mathrm{ppm}$ was used.

Fluid inclusion samples were collected from open pit through the ore-bearing veins and tunnels from discordant/second stage/ younger/Irish-type (codes Dsa4 and Dsa8) and concordant/1 $1^{\text {st }}$ stage/older/MVT of mineralization. Microthermometric analyses were performed to obtain a preliminary estimate of the temperatures and salinities of the ore-forming fluids. In this fluid inclusion study, we used standard techniques (STEELE et al., 2011) and a Linkam model THMS 600 heating-Freezing stage mounted on a Zeiss, Axioplan 2, imaging microscope with a temperature range between $-196{ }^{\circ} \mathrm{C}$ to $+600{ }^{\circ} \mathrm{C}$, at the Iran Mineral Processing Research Center (IMPRC), Karaj, Iran. This stage is equipped with two controllers, heating (TP94) and cooling (LNP), a nitrogen tank (for pumping nitrogen for freezing) and a water tank (for using the device at high temperature). The accuracy is estimated to be $\pm 0.2{ }^{\circ} \mathrm{C}$ on freezing (n-Hexane, melting point: $-94.3^{\circ} \mathrm{C}$ ) and $\pm 0.6^{\circ} \mathrm{C}$ on heating (Cesium nitrate, melting point: $+414{ }^{\circ} \mathrm{C}$ ).

\section{ORE DEPOSIT GEOLOGY}

\subsection{Structural geology and ore bodies}

Mineralization at the Duna Pb-Ba-(Ag) mine has been structurally controlled by the Duna anticline and faults and has chemically been affected by bituminous layers, dolomitic horizons, and impermeable volcanic rocks of Permian age. The structure of the Duna $\mathrm{Pb}-\mathrm{Ba}-(\mathrm{Ag})$ mine is characterized by a horizontal to overturned fold with an axis length of about $6 \mathrm{~km}$ in an E-W trend (Figs. 2, and 3a, b). In poly- orogenic systems, structural controls

Table 2. The REE analysis results (in ppm) of the investigated samples from the Duna mine including Ore, Host Rock (HR), lgneous Rock (IR) and Barite (Brt), Akapol intrusive (Ak), Bdl: Below detection limit; dis: discordant veins (mostly second stage/younger/lrish-type); con: concordant veins (mostly $1^{\text {st }}$ stage/older/MVT-type); dol: dolomite; mel: melaphyre unit.

\begin{tabular}{|c|c|c|c|c|c|c|c|c|c|}
\hline Sample & DSa1 & DSa2b & DSa4 & DSa7 & DSa17 & DSa5,26 & DSa6,24,28 & DSa8,14 & $\mathrm{A} 1-\mathrm{A} 2$ \\
\hline Rock Type & $\begin{array}{l}\text { Ore } \\
\text { (dis) }\end{array}$ & $\begin{array}{c}\text { Ore } \\
\text { (con) }\end{array}$ & $\begin{array}{l}\text { Ore } \\
\text { (dis) }\end{array}$ & $\begin{array}{c}\text { Ore } \\
\text { (con) }\end{array}$ & $\begin{array}{c}\text { Ore } \\
\text { (con) }\end{array}$ & $\begin{array}{c}\mathrm{HR} \\
\text { (dol) }\end{array}$ & $\begin{array}{c}\text { IR } \\
(\mathrm{Mel})\end{array}$ & $\begin{array}{c}\text { Brt } \\
\text { (dis) }\end{array}$ & $\begin{array}{c}\mathrm{Ak} \\
\text { (intrusive) }\end{array}$ \\
\hline $\mathrm{La}$ & $<1$ & 1 & $<1$ & $<1$ & $<1$ & 15 & 52 & 1.3 & 63.4 \\
\hline $\mathrm{Ce}$ & $<1$ & 2 & $<1$ & $<1$ & $<1$ & 33.5 & 113 & 2.3 & 106 \\
\hline $\operatorname{Pr}$ & 0.26 & 0.63 & 0.23 & 0.27 & 0.38 & 4.48 & 11.4 & 0.5 & 10.27 \\
\hline $\mathrm{Nd}$ & $<0.5$ & 1.3 & $<0.5$ & $<0.5$ & 0.6 & 19.7 & 42.1 & 1.05 & 33.7 \\
\hline $\mathrm{Eu}$ & $<0.1$ & 1.44 & 2.26 & 0.19 & $<0.1$ & 1.68 & 1.78 & 0.91 & 1.30 \\
\hline $\mathrm{Gd}$ & 0.6 & 0.73 & 0.56 & 0.6 & 0.69 & 4.19 & 6.43 & 0.69 & 3.32 \\
\hline $\mathrm{Tb}$ & $<0.1$ & $<0.1$ & $<0.1$ & $<0.1$ & $<0.1$ & 0.7 & 0.95 & $<0.1$ & 0.39 \\
\hline Dy & 0.12 & 0.18 & 0.08 & 0.12 & 0.19 & 3.74 & 6 & 0.21 & 1.83 \\
\hline $\mathrm{Ho}$ & Bdl & Bdl & Bdl & Bdl & Bdl & Bdl & & Bdl & 0.28 \\
\hline $\mathrm{Er}$ & $<0.05$ & $<0.05$ & $<0.05$ & $<0.05$ & $<0.05$ & 1.76 & 3.46 & $<0.05$ & 0.78 \\
\hline $\mathrm{Tm}$ & $<0.1$ & $<0.1$ & $<0.1$ & $<0.1$ & $<0.1$ & 0.25 & 0.49 & $<0.1$ & 0.1 \\
\hline $\mathrm{Lu}$ & $<0.1$ & $<0.1$ & $<0.1$ & $<0.1$ & $<0.1$ & 0.2 & 0.45 & $<0.1$ & 0.1 \\
\hline $\mathrm{Eu} / \mathrm{Eu}^{*}$ & & & 3.85 & & & 3.54 & 0.65 & 1.19 & 0.34 \\
\hline $\mathrm{Ce} / \mathrm{Ce}^{*}$ & & & 0.58 & & & 0.45 & 1.08 & 0.93 & 4.15 \\
\hline
\end{tabular}



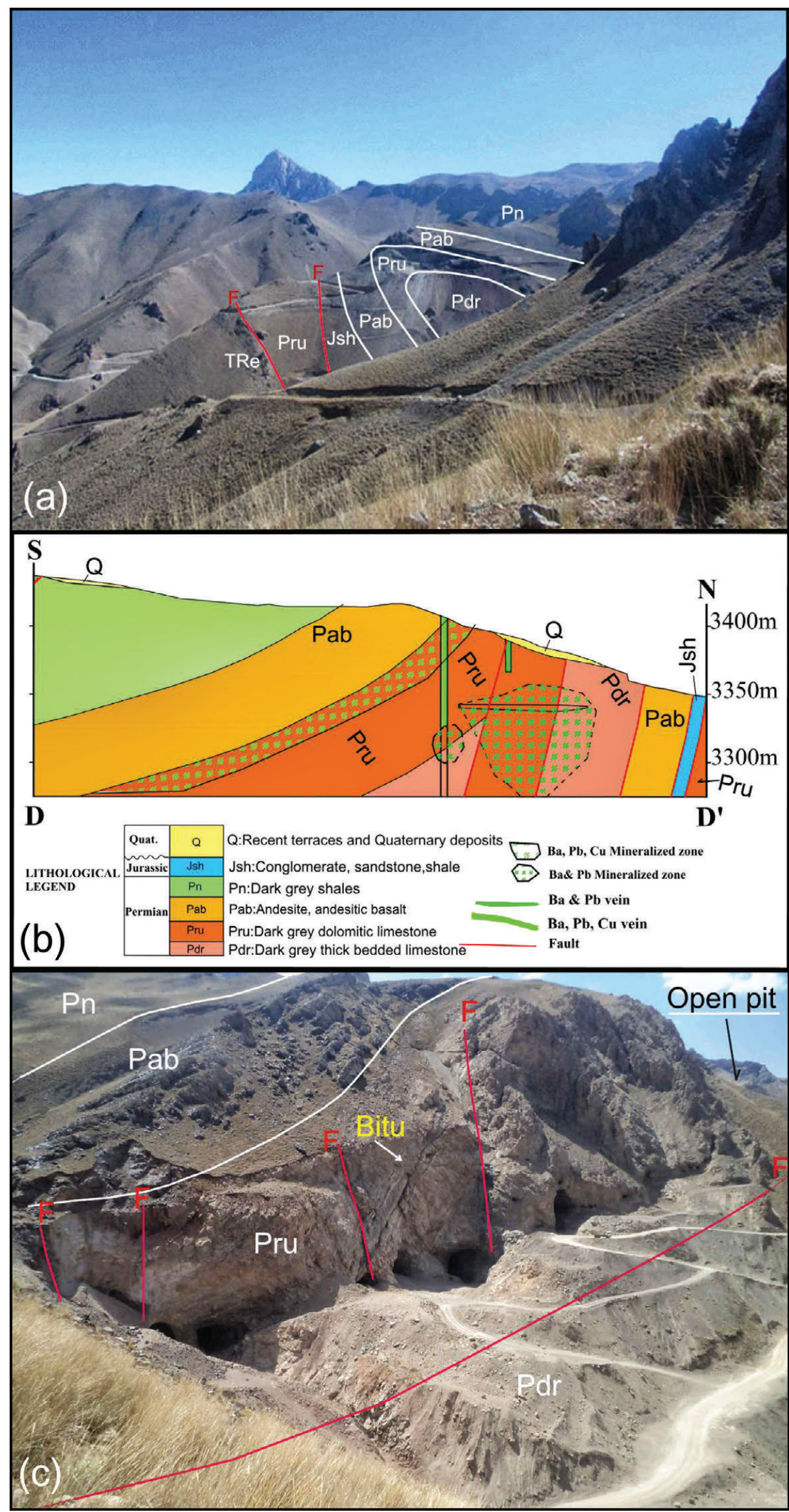

Figure 3. The relationship between the mineralization, structure, and host rock in the Duna mine. a) View of folding (anticline) in the open pit of the Duna mine (view to the east); b) The cross section (DD') of the geological map and mineralization position in the Dorud and Ruteh Formations; c) Field photograph showing the top fold (anticline) in the eastern district of the Duna mine (view to the south). Pdr-Dorud formation; Pru-Ruteh formation; Pn-Nessen formation; Pab-Melaphyre unit; Jsh-Jurassic formation; Q-Quaternary; Tre-Elika; Bitu-bituminous limestone. 
of ore bodies are often not easy to understand because the multiple phases of mineralization and the relationship between structures and ore bodies are not clear. The geological cross-section of the field observations (Fig. 2) displays the relationship between mineralized zones, bedding of host rocks, fractures, and structural forms. The Duna mining area is divided by F1 and F2 faults into the eastern, middle, and western blocks. The Permian rock units override to the north by these faults. The mineralization in the Duna mine has predominantly occurred in the dolomitic Ruteh Formation (Middle Permian) but also to some extent in the Dorud Formation (Lower Permian) (HOLZER \& MOMENZADEH, 1969), which are both exposed at the core of the Duna anticline (Figs. 2, and 3b). The lower part of the dolomitic Ruteh Formation is confined to a fault boundary while its upper part with highest mineralization is in contact with igneous rocks and bituminous limestone (Fig. 3c) (HAKIMI ASIABAR, 2019). It seems that bituminous limestone containing organic matter has changed the Eh-pH conditions of the mineralizing fluids and therefore enriched mineralization in these parts. In the eastern part of the mine, many extracting tunnels have been dug at the upper boundary of the mineralized Ruteh Formation (Fig. 3c).

The Ruteh and Durod Formations are exposed at the core of the Duna anticline (Fig. 2, cross sections; AA', BB', CC', and DD'). The tunnels are located in the central and eastern part of the Duna mine. Most of the mineralized veins in the tunnels have a northwest-southeast and east-west trend and follow the path of steep faults. These sections indicate an asymmetric fold in the Duna mine where most of the mineralization has occurred discordantly in the normal edge of the fold, in the dolomitic Ruteh Formation and its contact with melaphyre rocks (pab), which mostly indicates the second stage/younger/Irish-type of mineralization. The Section DD' is located in the western part of the Duna mine and in the position of the open pit. Stratabound and stratiform mineralization of the copper-barite-lead slope can be seen throughout the contact of dolomitic Ruteh Formation and igneous rocks which are mostly indicative of the $1^{\text {st }}$ stage/older/ MVT-type of mineralization. This stratabound mineralization has occurred in the faulted Permian limestone and dolomitic rocks, which are overlain by andesitic basalt (Pab) of the Late Permian (Fig. 3b, c). The melaphyre unit (Pab) is very dense and as an impermeable rock unit has acted like a confining barrier for limiting the mineralizing fluids in the top level of the Duna mine.

According to the rose diagrams (Fig. 2), three major thrust fault generations were recognized in the study area (HAKIMI ASIABAR, 2019). Most of the thrust faults of the geological map area have approximately W-E and WSW-ENE directions. The first generation of thrust faults (due to the Laramide orogeny), with WSW-ENE strike is parallel to the major fold axis and dominated by reverse movement with a right-lateral component. Approximately $65 \%$ of these faults hold mineralization in their brecciated zones (HAKIMI ASIABAR, 2019). Most of these faults cropped out on the overturned layers of the Duna anticline. The second group of fault sets (due to the Pyrenean orogeny), with a nearly E-W trend and a reverse sense, is not parallel to the fold axis of the Duna anticline and bedding surface of the layers. The third category of faults with an approximate trend of N30W to $\mathrm{N} 40 \mathrm{~W}$ intersects the first and second fault set. According to field observations, the first and second generations of thrust faults, contain mineralized zones, but the third fault set is barren and does not have any mineralized zone, which indicates overlapping of oreforming events predating the third faulting episode. Each generation of thrust faults is usually accompanied with some strikeslip faults, diagonal to its trend. Many mineralized veins and veinlets occurred along strike-slip faults as a result of folding processes affecting the layers (HAKIMI ASIABAR, 2019). The mineralization of concordant veins during the Permian and Triassic periods has occurred in the $1^{\text {st }}$ stage/older/MVT while the mineralization along the first and second generations of thrust faults occurred in the second stage/younger/Irish-type of mineralization.
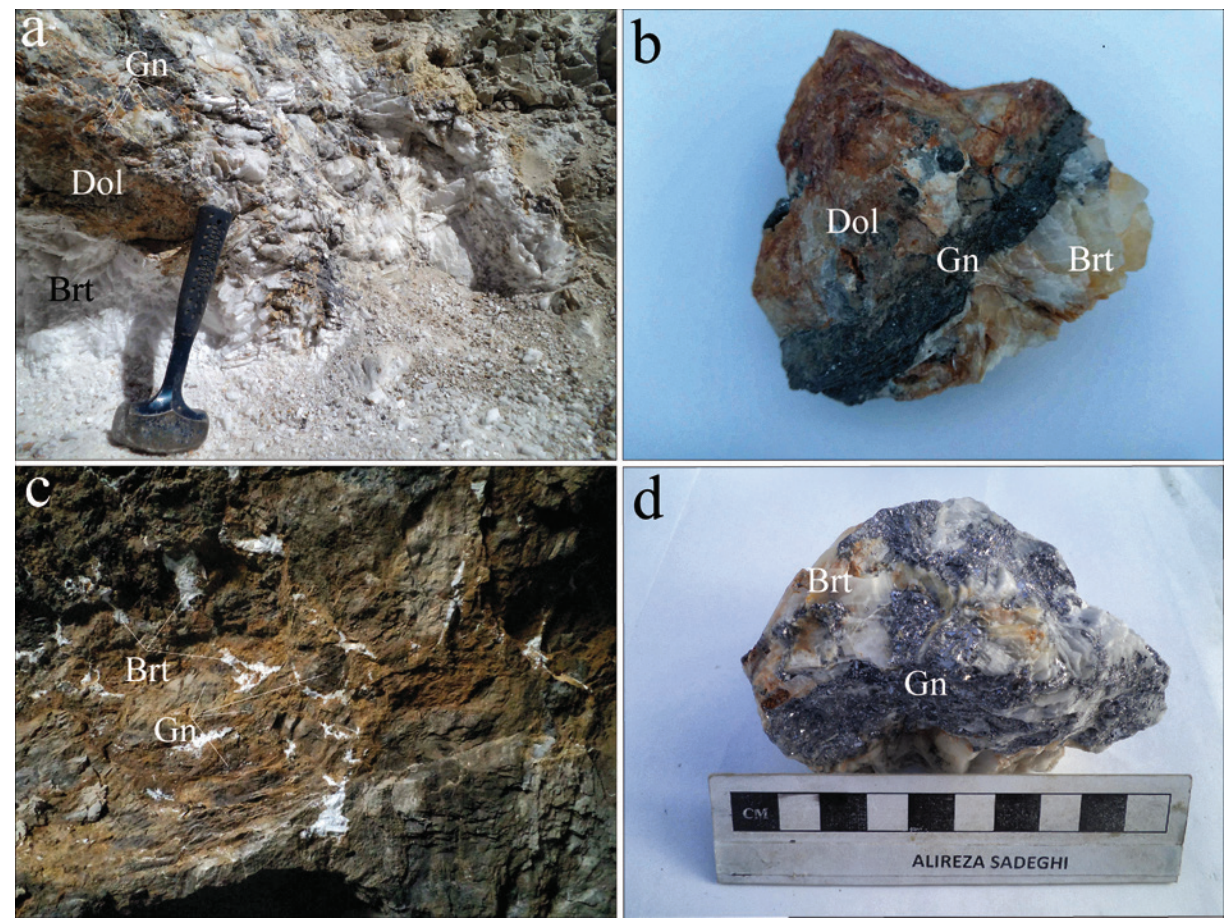

Figure 4. Hand specimens and field photograph of galena and barite mineralization in the Duna mine. a) Galena (Gn) and Barite (Brt) mineralization in dolomitic host rock as open space filling of open pit/1 ${ }^{\text {st }}$ stage/older/MVT; b) mineralized vein of galena in hand specimen; c) disseminated barite in tunnel/ second stage/ younger/lrish-type; d) hand specimen of high-grade galena. 

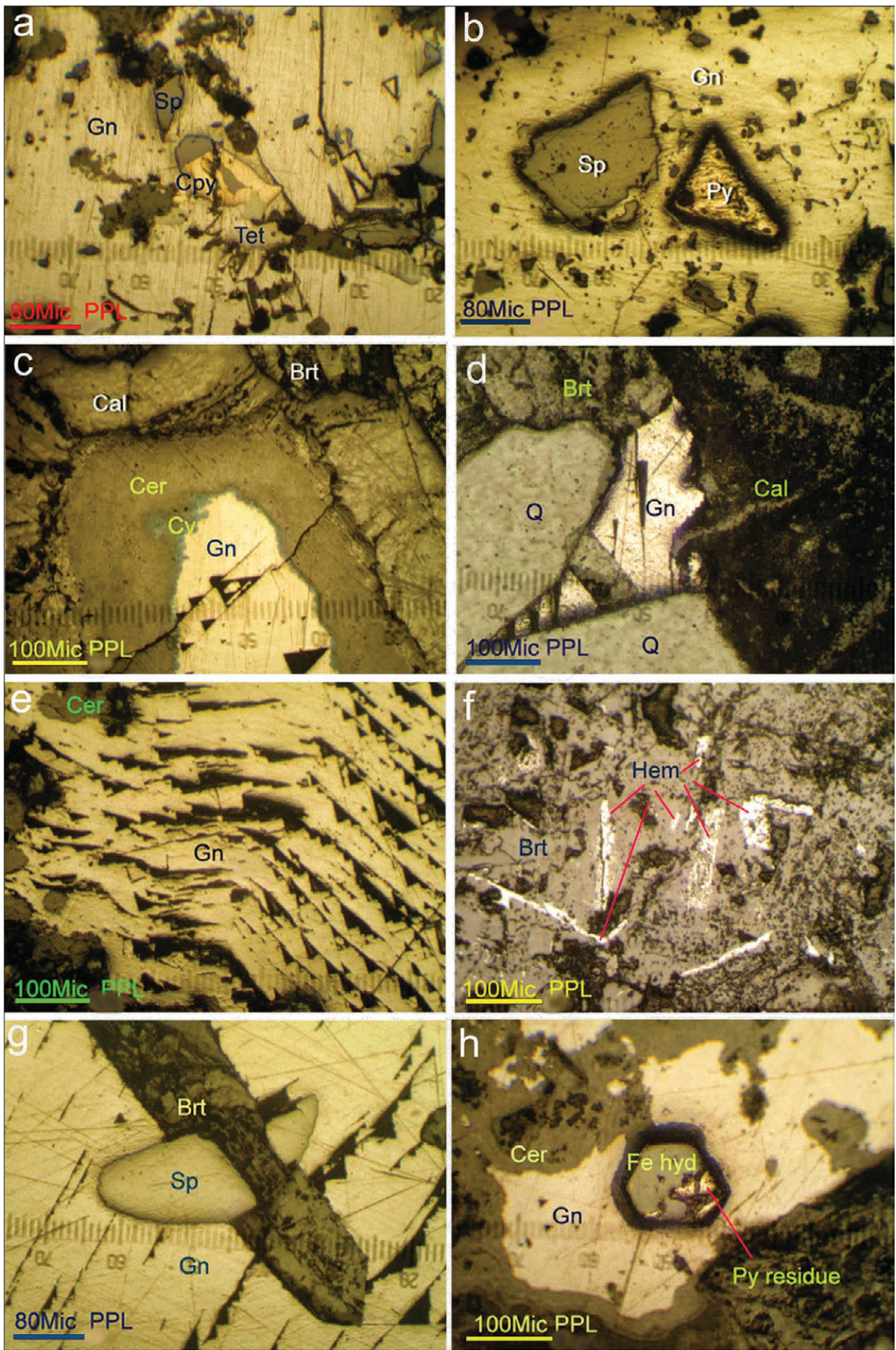

Figure 5. Photomicrographs of minerals in the Duna mine. a) replacement tetrahedrite, sphalerite, and chalcophyrite in galena from the open pit; b) pyrite and sphalerite in galena from the open pit; c) aleration of galena to cerussite and covellite within the calcite and barite from the open pit; d) galena as a filled veinlet of fractures between quartz, calcite and barite from the tunnel; e) curved shape of galena from the tunnel; $f$ ) haematite blades in barite from the open pit; $g$ ) alteration of crystalline euhedral pyrite to iron hydroxide and galena alteration from margins to cerussite from the tunnel; $h$ ) sphalerite inclusion in galena from the tunnel. Brt-Barite; Cal-Calcite; Cp-Chalcopyrite; Cv-Covellite;Cal-Calcite; Gn-Galena; Hem-Haematite; Py-Pyrite; Qz-Quartz; Cer-Cerrussite; SI-Sphalerite;Tt-Tetrahedrite. Figures a, b, c and f are from the open pit/mostly $1^{\text {st }}$ stage/older/MVT and figures $\mathrm{d}, \mathrm{e}, \mathrm{g}$ and $\mathrm{h}$ are from the tunnel/second stage/younger//rish-type. Symbols from Whitney and Evans, (2010).

\subsection{Ore mineralogy, Texture and Paragenesis}

Based on the field observations, galena and barite are the most important minerals that have often occurred simultaneously (Fig. 4a-d). Mineralization in the Duna mine occurred predominantly in the structural open-spaces of the dolomitic host rock. A mas- sive mineralization of galena and barite with dimensions of more than 3 metres was formed as open space fillings, especially in shear zones (Fig. 4a). The size of galena and barite mineralization in veins, veinlets, and in dissemination form (Fig. 4b, c) is from about a few millimetres to a few tens of centimetres. A dis- 
Table 3. Results of the microprobe analyses (EPMA) (Wt. \%) in an ore sample from a discordant vein (code DSa1). Tt: tetrahedrite; Gn: galena; SI: Sphalerite and (*: Below detection limit).

\begin{tabular}{|c|c|c|c|c|c|c|c|c|c|c|c|c|c|c|}
\hline Mineral & Points & $\mathrm{Pb}$ & $\mathrm{Zn}$ & $\mathrm{Ag}$ & As & $\mathrm{Cu}$ & $\mathrm{Sb}$ & $\mathrm{Bi}$ & $\mathrm{Fe}$ & $\mathrm{Ga}$ & $\mathrm{Cd}$ & $\mathrm{Au}$ & $S$ & Total \\
\hline $\mathrm{Tt}$ & 1 & 0.18 & 7.2 & 2.51 & 9.83 & 37.64 & 15.52 & 0.28 & 0.6 & $*$ & $*$ & 0.04 & 26.57 & 100.4 \\
\hline $\mathrm{Tt}$ & 2 & 0.28 & 7.32 & 4.23 & 5.56 & 34.74 & 22.29 & 0.15 & 0.52 & $*$ & * & 0.03 & 25.37 & 100.5 \\
\hline $\mathrm{Tt}$ & 3 & 0.19 & 7.82 & 4.25 & 6.03 & 34.45 & 21.54 & 0.21 & 0.43 & * & * & * & 25.77 & 100.7 \\
\hline $\mathrm{Tt}$ & 10 & 0.08 & 8.32 & 2.13 & 11.09 & 37.14 & 15.13 & 0.14 & 0.66 & * & * & * & 26.02 & 100.7 \\
\hline Gn & 4 & 87.08 & * & 0.04 & * & * & * & 0.36 & 0.11 & 0.04 & 0.03 & * & 13.27 & 100.9 \\
\hline Gn & 5 & 86.31 & * &.$*$ & * & $*$ & * & 0.41 & 0.15 & 0.01 & $*$ & * & 13.41 & 100.3 \\
\hline Gn & 6 & 86.03 & * & $*$ & $*$ & * & * & 0.46 & 0.11 & 0.02 & 0.11 & $*$ & 13.91 & 100.8 \\
\hline Gn & 12 & 86.96 & * & $*$ & $*$ & 0.13 & $*$ & 0.5 & 0.1 & 0.08 & * & 0.04 & 13.12 & 100.9 \\
\hline $\mathrm{SI}$ & 7 & 0.24 & 65.17 & $*$ & * & $*$ & 0.06 & 0.18 & 0.08 & * & 0.56 & * & 33.81 & 100.1 \\
\hline $\mathrm{SI}$ & 8 & 0.34 & 66.5 & * & 0.02 & $*$ & $*$ & 0.08 & $*$ & 0.06 & 0.55 & $*$ & 33.23 & 100.8 \\
\hline SI & 9 & 0.11 & 65.06 & 0.06 & * & * & 0.01 & 0.15 & 0.09 & 0.02 & 0.58 & $*$ & 33.26 & 99.34 \\
\hline SI & 11 & 0.2 & 65.44 & * & $*$ & $*$ & 0.04 & 0.05 & 0.07 & * & 0.54 & * & 33.49 & 99.83 \\
\hline
\end{tabular}

seminated texture has occurred due to replacement and/or openspace filling.

Microscopic study of the samples collected from both concordant and discordant mineralization (Fig. 5) demonstrates two stages; the mineralization in the first (older) stage of Mississippi Valley-type and the second (younger) stage of Irish-type. Based on the microscopic and macroscopic studies, galena is the main ore mineral while sphalerite, tetrahedrite, pyrite, and chalcopyrite comprise the accessory ore minerals. Barite, dolomite, calcite and quartz are the gangue minerals. Supergene minerals include Fe-oxides, covellite, cerussite, anglesite, malachite, and azurite.

\subsubsection{Ore mineralogy, Texture and Paragenesis in the $1^{\text {st }}$ stagel older/MVT}

The concordant mineralization in the Duna mine has mostly occurred in the $1^{\text {st }}$ stage older/MVT. Microscopic study of three samples collected from the concordant veins (Dsa7; Fig. 5b, Dsa17; Fig. 5e, and Dsa5; Fig. 5f) shows that galena is the main ore mineral in the $1^{\text {st }}$ stage, that occurs as anhedral disseminated grains and open space filling (Fig. 5b). The curved shape in some galena is a sign of mechanical (tectonic) pressures on the rock after formation of the ore mineral (Fig. 5e). Barite is the main gangue mineral that was deposited before and during the $1^{\text {st }}$ stage /older/MVT (Fig. 5f). In Fig. 5b, sphalerite and chalcopyrite have a replacement state with each other and with galena. Pyrite was formed before the main mineralization phase and its anhedral crystals are usually surrounded by galena (Fig. 5b). Pyrite was formed with open space filling and disseminated euhedral grains in the siliceous veins and veinlets at the $1^{\text {st }}$ stage/younger/MVT of mineralization (Fig. 5b). Cerussite is formed around galena by secondary processes or supergene alteration (Fig. 5e) while quartz was formed as microcrystalline euhedral grains (average $12 \mu$ in size) and also is scattered as siliceous veins in the host rock in the $1^{\text {st }}$ stage. Dolomite as a gangue mineral has occurred during dolomitization before the main mineralization stage.

\subsubsection{Ore mineralogy, Texture and Paragenesis in the second stage/younger/lrish-type mineralisation}

The samples that were related to the second stage/younger/ Irish-type of mineralization were collected from the discordant veins including the samples of DSa1 (Fig. 5a, b), DSa4 (Fig. 5 c), DSa12 (Fig. 5h) and DSa13 (Fig. 5g). Dolomitic alteration in the host rock of the Ruteh carbonate formation has produced more space for mineralization (Fig. 6a). Galena is the main ore mineral and occurs as anhedral disseminated grains (a few microns in size), open space filling (Fig. 5a), and veinlets (up to $3 \mathrm{~mm}$ ) (Fig. $5 d)$. Galena is seen both undisturbed and altered from the margins into covellite and cerussite (Fig. 5c, h). Galena together with sphalerite, tetrahedrite, chalcopyrite and pyrite shows open space filling texture (Fig. 5a). Barite is a main gangue mineral that has filled voids, open spaces, cavities, and fractures in the host rock in the forms of layers, scattered plates, patches, and as a massive mineral with a few mm to 3 meters length. Some metallic sulfide minerals are scattered among the barite grains. Barite was deposited before and during the second stage/younger/Irish-type of galena mineralization, although they have mostly occurred contemporaneously (Fig. 5c, d, h). Barite is often impregnated with calcium carbonate (Fig. 5d). Sphalerite together with tetrahedrite and chalcopyrite were mostly formed in the second stage/younger/ Irish-type of mineralization (Figs. 5a, g) that are in some cases surrounded by galena (Fig. 5a, b, h). The frequency of sphalerite is about $5 \%$. Anhedral spots of sphalerite with dimensions of 2 to $20 \mathrm{~mm}$ are observed. Sphalerite sometimes occurs as inclusions in galena (Fig. $5 \mathrm{~g}$ ). Co-precipitation of sphalerite and chalcopyrite occurred in the second stage/younger/Irish-type of mineralization (Fig. 5a). Pyrite euhedral crystals are usually surrounded by galena (Fig. 5g) and are also embedded in the barite as veinlet and open space fillings with other sulfide minerals. Pyrite is a common sulfide mineral in many carbonate-hosted $\mathrm{Zn}-\mathrm{Pb}$ deposits (LEACH et al., 2005). Some pyrite grains have been transformed into iron hydroxides as a result of supergene alteration (Fig. $5 \mathrm{~g}$ ). Cerussite is formed around galena by secondary processes or supergene alteration in the second stage (Fig. 5c).

Quartz is usually found in the hydrothermal breccia and brittle shear zones which shows the hydrothermal origin of some fluids. Quartz veins that sometimes contain galena, pyrite, and carbonates were formed during the $1^{\text {st }}$ stage/ older/MVT while hydrothermal quartz is formed in the second stage/younger/Irishtype of mineralization (Figs. 5d and 6a). Silica has usually accompanied the hydrothermal fluids in the main mineralization stage and has manifested as silicification.

Calcite was formed in the late stage of galena and barite mineralization and surrounds these minerals (Fig. 5d). The rock texture is composed of micrite.

The secondary minerals in the $1^{\text {st }}$ stage/ older/MVT and the second stage/younger/Irish-type of mineralization include Feoxy-hydroxides (Figs. 5g and 6a), cerussite (Fig. 5c, e, g), covellite (Fig. 5c), anglesite (Fig. 6a) malachite and azurite (Fig. 6b), that were formed by oxidation processes of the sulfide minerals near the surface. Anglesite is a secondary lead mineral, gray to yellow in colour and has occurred in the oxidized zone of the lead deposit and often surrounds galena. The paragenetic sequence of the Duna $\mathrm{Pb}-\mathrm{Ba}-(\mathrm{Ag})$ mine is shown in figure 7. 

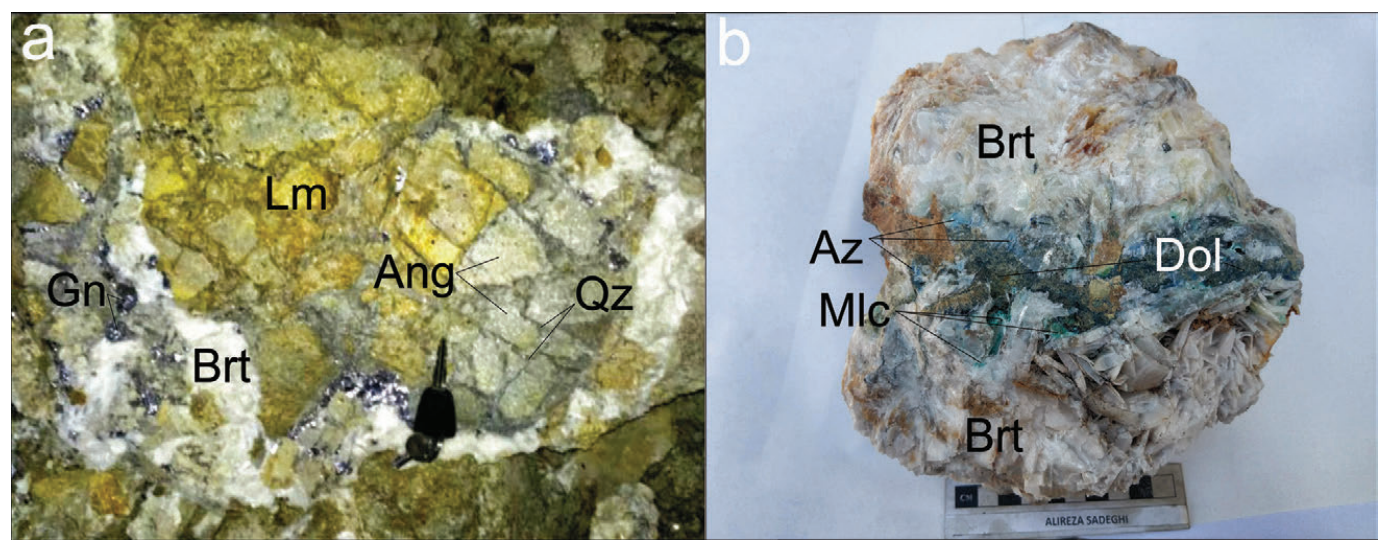

Figure 6. a) Brecciated texture with? mineralized quartz veinlets as open space filling of dolomite limestone and mineralization of anglesite and limonite in the core of the galena and barite from the tunnel/second stage/younger/lrish-type; b) The mineralization of the malachite and azurite in barite with boxwork texture from the open pit/1 ${ }^{\text {st }}$ stage/older/MVT. Ang-Anglesite; Az-Azurite; Brt-Barite; Dol-Dolomite; Gn-Galena; Mlc-Malachite; Qz-Quartz. Symbols from Whitney and Evans, (2010).

\subsubsection{Electron Probe Microanalysis (EPMA)}

For a more detailed study on the $\mathrm{Ag}$ and other trace elemental content of the ore, Electron Probe Microanalysis (EPMA) was performed at twelve points on tetrahedrite, galena, and sphalerite minerals of an ore sample (Fig. 8), at the Iranian Mineral Processing Research Center (IMPRC) laboratory (table 3). Tetrahedrite occurs as a replacement in galena in the first and more in the second stage, and in the early stage of galena mineralization. Some anhedral tetrahedrite occurs as an open space filler in the barite crystals. Based on these investigations, zinc is concentrated in sphalerite and to some extent in tetrahedrite, while Ag, $\mathrm{As}, \mathrm{Sb}$ and $\mathrm{Cu}$ are concentrated in the tetrahedrite mineral network that formed before galena based on the mineral paragenesis. The amount of silver in the tunnels (mostly in discordant veins) has been reported to reach up to $7030 \mathrm{ppm}$ by the Damavand Mining Company (2013), measured at the Ayarjouyan Novin laboratory, Iran.

\section{RESULTS}

\subsection{Geochemistry}

The contents of the major, trace, and rare earth elements according to ICP-MS of the Duna mine are given in Tables 1 and 2. The samples DSa1 and DSa4 represent the discordant/second stage/ younger/Irish-type of mineralization, while samples DSa2b,
DSa7, and DSa17 represent the concordant $/ 1^{\text {st }}$ stage older/MVT of mineralization.

The average grade of the ore for $1^{\text {st }}$ stage/older/MVT and second stage/younger/Irish-type of mineralization is 19.5 and 18.1 wt. \% Pb, 53.5 and 2541 ppm Zn, 81.1 and 146.6 ppm Ag, 26.1 and $1132.7 \mathrm{ppm} \mathrm{As,}, 140$ and $14310 \mathrm{ppm} \mathrm{Cu}, 469.5$ and 66.3 ppm Mn, 53.8 and 3875 ppm Sb, 233 and 9200 ppm Sr, respectively. Also the content of elements like Mo, $\mathrm{U}, \mathrm{Cd}, \mathrm{Te}$, and $\mathrm{Tl}$ is in some cases considerable. While the content of the above-mentioned elements is higher in the ore compared to the dolomitic host rock and igneous rocks, these rocks are more enriched in the following elements in comparison with the ore; $\mathrm{Fe}, \mathrm{Mg}, \mathrm{Co}, \mathrm{Cr}$, Cs, Mn, Sn, Th, Ti, V, and W.

The chondrite-normalized REE patterns (BOYNTON, 1984) in all samples of ore, dolomitic host rock, igneous rock, and barite in the Duna Pb-Ba-(Ag) mine and the Akapol intrusive mass (SAJJADINASAB et al., 2000; PASSAND MAUSOUMI et al., 2001), indicate enrichment of LREE relative to HREE, while all samples show a fractionation from La to $\mathrm{Yb}$ (Fig. 9). The HREE concentrations of the ore are more depleted than the $\mathrm{LREE}_{\mathrm{S}}-\mathrm{MREE}_{\mathrm{S}}$.

The chondrite-normalized values of the mineralized host rocks are 1.8 to $2.3 \mathrm{ppm}$ for La and less than $0.05 \mathrm{ppm}$ for $\mathrm{Yb}$. The same values for the unmineralized host rock are 35 to $40 \mathrm{ppm}$ for $\mathrm{La}$ and about $9.8 \mathrm{ppm}$ for $\mathrm{Yb}$, while in the igneous rock they

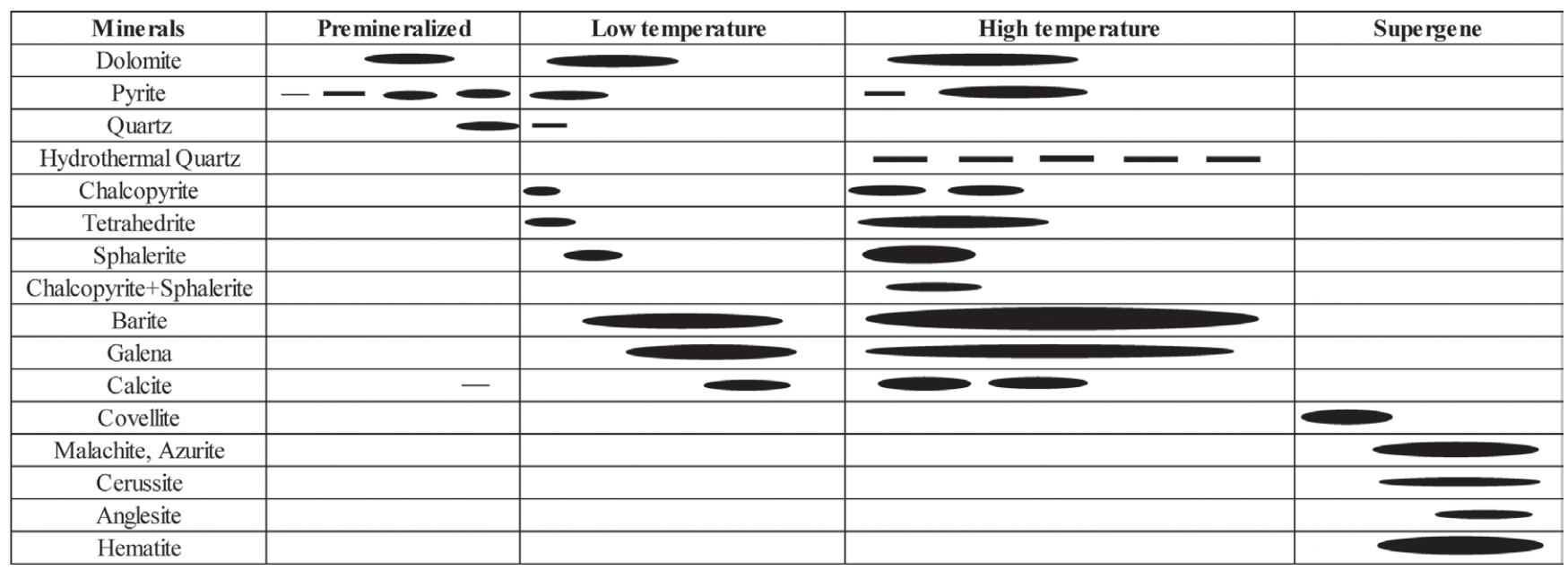

Figure 7. Summary of the paragenetic sequence of the two stage mineralization; $1^{\text {st }}$ stage/older/MVT and second stage/younger//rish-type in the Duna mine. 


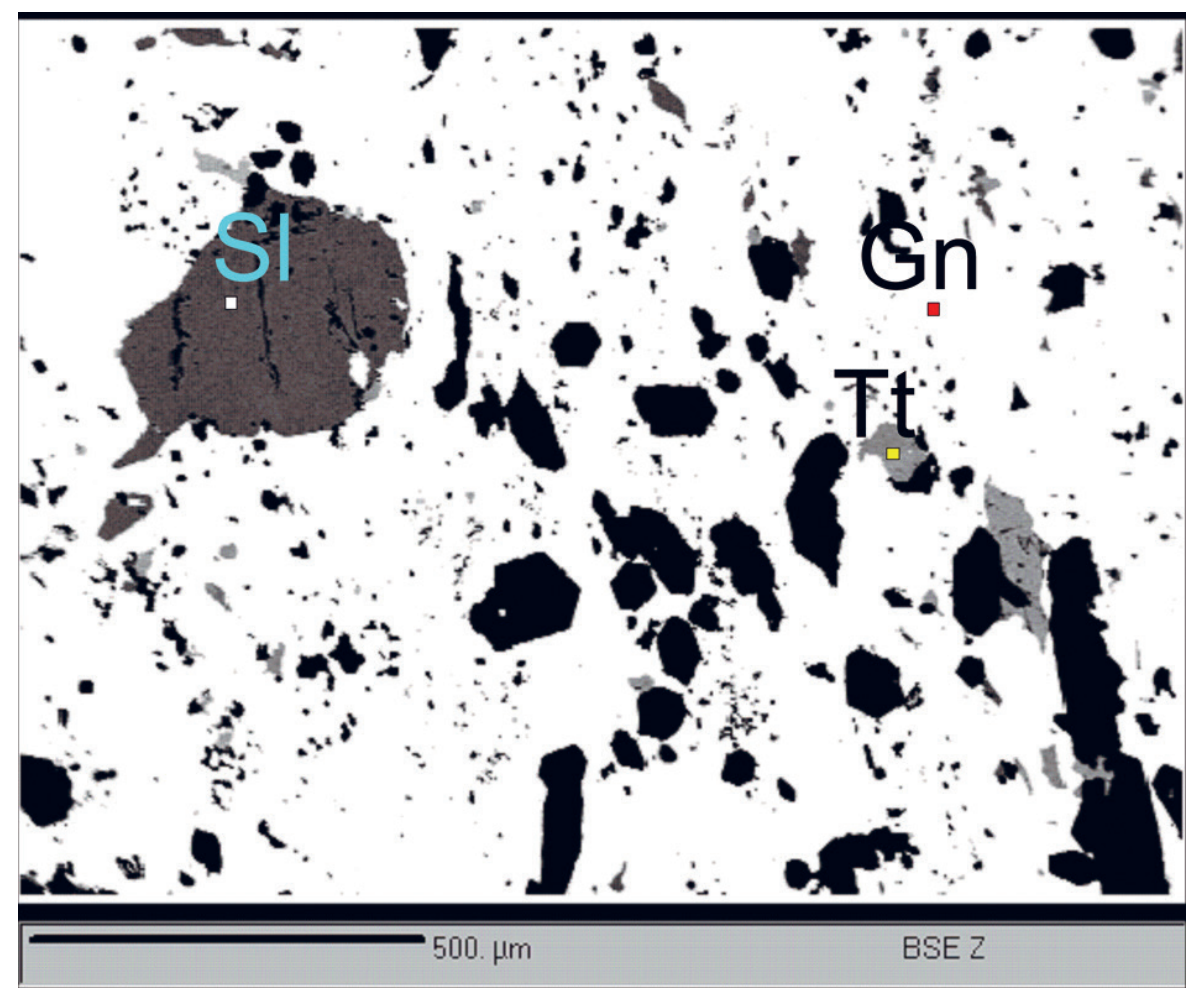

Figure 8. Electron Probe Microanalysis (EPMA) images for Tetrahedrite (Tt), Galena (Gn), and Sphalerite (SI).

indicate 30 to 400 ppm for La and 20 to 60 ppm for Yb. The total amounts of REE ( $\Sigma$ REE) are very low and fall in the ranges of 2.19-9.69 ppm for ore samples, while the average is $8.7 \mathrm{ppm}$ for barite. On the other hand, the average REE amounts ( $\mathrm{REE}$ ) are about $244.9 \mathrm{ppm}$ for the melaphyre unit (Igneous rock), $89.74 \mathrm{ppm}$ for the dolomitic host rock and 225.8 ppm for the Akapol intrusive mass. Remarkably, the patterns presented in Fig. 9 show that the REE values in the ore and barite in the first and second stage of mineralization are neither similar to the samples of igneous rock, dolomitic host rock, nor the Akapol intrusive mass. The chondrite-normalized REE patterns of Eu and Ce (MC LENNAN, 1989), for ore samples, indicate negative Ce (varying from $<1$ to 2 ) and strong positive $\mathrm{Eu}$ (varying from $<0.1$ to 2.26 ) anomalies, and were calculated using the following formula; $\left(\mathrm{Eu} / \mathrm{Eu}^{*}=\right.$ $\mathrm{Eu}_{\mathrm{N}} /\left[\left(\sqrt{ } \mathrm{Sm}_{\mathrm{N}} \times \sqrt{\mathrm{Gd}_{\mathrm{N}}}\right)\right] \& \mathrm{Ce} / \mathrm{Ce}^{*}=\mathrm{Ce}_{\mathrm{N}} /\left[\left(\sqrt{ } \mathrm{La}_{\mathrm{N}} \times \sqrt{ } \mathrm{Pr}_{\mathrm{N}}\right)\right]$, $\mathrm{N}=$ Normalized). The chondrite-normalized REE patterns of Eu and Ce for igneous and host rocks, show weak negative Ce and weak positive Eu.

\subsection{Fluid inclusion}

Fluid inclusions were studied from barite of concordant and discordant veins in the tunnel and the open pit. The sample DSa2a was taken from the concordant veins and represents the $1^{\text {st }}$ stage/ older/MVT of mineralization, while samples DSa4 and DSa8 were taken from the brecciated area of fault zones and discordant layers which represents the second stage/younger/Irish-type of mineralization. Barite was selected for the study of the fluid inclusions due to its transparency and presence in the main mineralization stage. A total of 62 fluid inclusions from four doubly polished-thin sections were measured (Table 4).

\subsubsection{Study of fluid inclusions in the $1^{\text {st }}$ stage/ older/MVT}

Petrographic studies of fluid inclusions in the first stage of mineralization in the barite samples distinguished two types of inclusions: liquid-vapour (L-V) and less common mono-phase liquid (Fig. 10a, c). The liquid-vapour (L-V) inclusions (Fig. 10a) hosted in barite are liquid rich. The liquid/vapour ratio is 70 to 80 in these inclusions. The fluid inclusions are of primary origin but a number of fluid inclusions in micro-cracks cutting with linear arrangement in different directions can indicate the secondary origin or the next generation of the inclusions as a result of stress and joint formation in the study area (Fig. 10c). The size of fluid inclusions with elongate and regular polyhedral shapes is 5 to $25 \mu \mathrm{m}$ in the concordant layers.

Microthermometric measurements in the $1^{\text {st }}$ stage veins were performed on the primary two-phase (L-V) inclusions (Tab. 4). The first melting temperature (Tfm) that corresponds to the eutectic temperature is $-55^{\circ} \mathrm{C}$ to $-45^{\circ} \mathrm{C}$ for all fluid inclusions. This low temperature that is due to the drop in freezing point of pure water depends on the type of salt $\left(\mathrm{NaCl}, \mathrm{CaCl}_{2}\right.$, and $\left.\mathrm{KCl}\right)$ in the

Table 4. Fluid inclusion studies data in barite from both the open pit and a tunnel in the Duna mine. N: number of fluid inclusion; TFM: temperature of first melting; TM: temperature of last melting; TM-hh:Temperature of melting hydrohalite; $\mathrm{TH}$ : Temperature of homogenization; $\mathrm{nm}$ : Not measured; dis: discordant veins (mostly second stage/younger/Irish-type); con: concordant veins (mostly $1^{\text {st }}$ stage/older/MVT).

\begin{tabular}{lccc}
\hline $\begin{array}{l}\text { Sample Code } \\
\text { Location }\end{array}$ & $\begin{array}{c}\text { DSa2a } \\
\text { open pit (con) }\end{array}$ & $\begin{array}{c}\text { DSa4 } \\
\text { open pit (dis) }\end{array}$ & $\begin{array}{c}\text { DSa8 } \\
\text { Tunnel (dis) }\end{array}$ \\
\hline Host & Barite & Barite & Barite \\
$\mathrm{N}$ & 17 & 21 & 24 \\
Size $(\mu \mathrm{m})$ & 5 to 25 & 7 to 25 & 10 to 80 \\
Inclusion Type & $\mathrm{L}+\mathrm{V}$ & $\mathrm{L}+\mathrm{V}$ & $\mathrm{L}+\mathrm{V}$ \\
$\mathrm{TFM}\left({ }^{\circ} \mathrm{C}\right)$ & -55 to -45 & -55 to -45 & -55 to -45 \\
$\mathrm{TM}\left({ }^{\circ} \mathrm{C}\right)$ & -11.5 to -24 & -4.3 to -23.5 & -7.9 to -20.5 \\
$\mathrm{TFM} \mathrm{hh}\left({ }^{\circ} \mathrm{C}\right)$ & -25 to -27 & -25 to -34 & -18 to -23.5 \\
$\mathrm{NaCl}($ wt. $\%)$ & 8.29 to 22.2 & 3.96 to 13.02 & 9.05 to 17.12 \\
$\mathrm{CaCl} 2($ wt. $\%)$ & 7.82 to 13.21 & 3.38 to 16.98 & 2.46 to 6.02 \\
$\mathrm{NaCl}+\mathrm{CaCl} 2$ (wt. \%) & 18.54 to 23.65 & 7.34 to 22.76 & 11.78 to 22.29 \\
$\mathrm{TH}\left({ }^{\circ} \mathrm{C}\right)$ & 135 to 165 & 113 to 268 & 187 to 285 \\
\hline
\end{tabular}




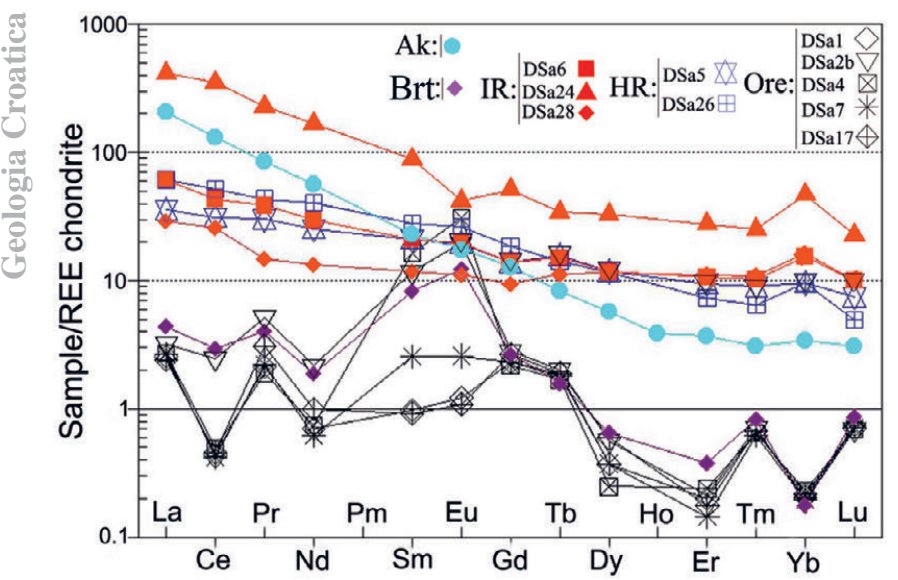

Figure 9. Chondrite-normalized REE patterns (BOYNTON, 1984) for samples from ore, host rock (HR), igneous rock (IR), and barite (Brt) in the Duna mine and the Akapole intrusive mass (Ak). REE-pattern irregularities of the ore, as a result of mixing of two mineralizations; $1^{\text {st }}$ stage/older/MVT and second stage/younger/Irish-type.

solution and is related to the salt system (SHEPHERD et al., 1985). This suggests that the ore-forming fluids that precipitated the barite and galena were hydrothermal fluids containing $\mathrm{NaCl}$ and $\mathrm{CaCl}_{2}$. The melting point of hydrohalite (Tmhh) in the fluid inclusions has a range of $-27^{\circ} \mathrm{C}$ to $-25^{\circ} \mathrm{C}$, which indicates the different ratios of $\mathrm{NaCl} / \mathrm{NaCl}+\mathrm{CaCl} 2$ (GOLDSTEIN \& REYNOLDS, 1994). The last ice melting temperature $\left(\mathrm{Tm}_{\text {ice }}\right)$ of the inclusions ranged from $-23.5^{\circ} \mathrm{C}$ to $-4.3{ }^{\circ} \mathrm{C}$ (average $-17.2{ }^{\circ} \mathrm{C}$ ). The relationship between the last ice melting and salinity (wt. \% $\mathrm{NaCl}$ eq.) shows the salinity of the ore-forming fluids (SHEPHERD et al., 1985). All inclusions in the $1^{\text {st }}$ stage of mineralization homogenized between $135^{\circ} \mathrm{C}$ to $165^{\circ} \mathrm{C}$ (average $161.5^{\circ} \mathrm{C}$ ). The salinity of fluid inclusions $(\mathrm{NaCl}+\mathrm{CaCl} 2 \mathrm{wt} . \%)$, ranged from 18.54-23.65 wt. $\% \mathrm{NaCl}$ equivalent (Average 19.92 wt. $\% \mathrm{NaCl}$ equivalent).

\subsubsection{Study of fluid inclusions in the second stage //younger/ Irish-type}

Petrographic studies of fluid inclusions in the discordant/second stage/younger/Irish-type of mineralization in the barite samples distinguished three types of inclusions: liquid-vapour (L-V), mono-phase liquid and mono-phase vapour (V) in the DSa4 sample (Fig. 10b). The simultaneous absence of liquid-rich and vapour-rich two-phase inclusions indicates the lack of boiling in the area (MONCADA et al., 2012; HASHEMIAN et al., 2018). However, the presence of mono-phase gas can indicate local boiling of the fluid as a result of pressure reduction at the fractures and faults in the second stage/younger/Irish-type of mineralization. The fluid inclusions of primary origin are characterized by the large size of the host crystal, and their separation from adjacent inclusions (SHEPHERD et al., 1985) that are interpreted as representing the ore-forming fluids. Most of the fluid inclusions are in elongate and regular polyhedral shapes with sizes ranging from 7 to $80 \mu \mathrm{m}$. The elongation of some fluid inclusions can be indicative of tectonic stresses in the area (HASHEMIAN et al., 2018). Fluid inclusions in the barite samples in the discordant layers are larger in size $(7-80 \mu \mathrm{m})$ of the concordant layers $(5-25$ $\mu \mathrm{m})$. The liquid/vapour ratio is $70: 80$. The inclusion contents homogenized into a liquid phase upon heating, indicate mineralization under hydrothermal conditions with no boiling in the formation of the fluids involved (SHEPHERD et al., 1985). Necking down, which is a phenomenon of dividing large, wide, and irregular primary inclusions into a number of smaller and more regular inclusions (SHEPHERD et al., 1985) is seen in some sections (Fig. 10d).

Microthermometric measurements in the second stage/ younger/Irish-type of mineralization were performed on the primary two-phase (L-V) inclusions (Table 4). The temperature of first melting (Tfm) is $-55^{\circ} \mathrm{C}$ to $-45^{\circ} \mathrm{C}$ for all fluid inclusions. The melting point of hydrohalite (Tmhh) in the inclusions has a range

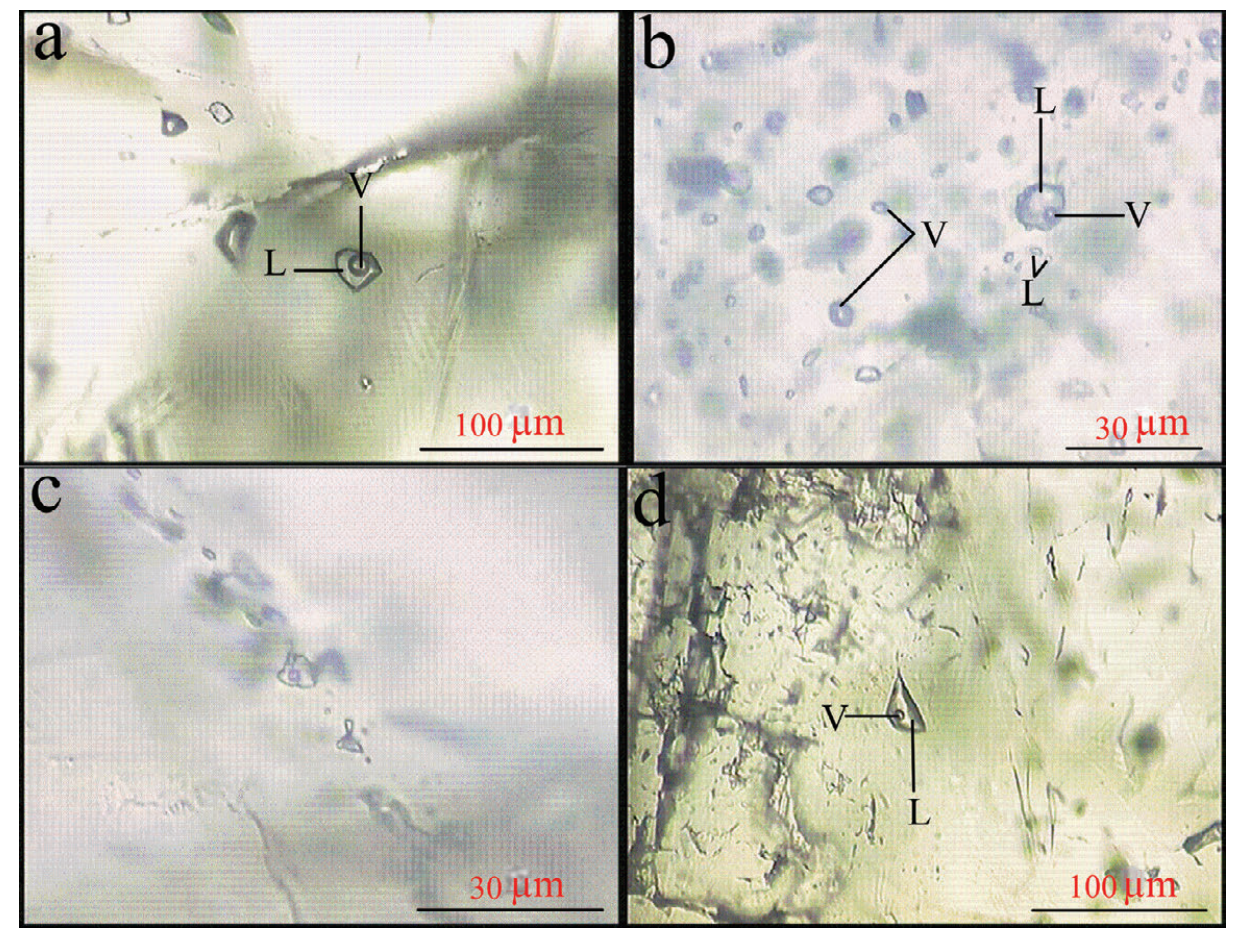

Figure 10. a) Photomicrograph illustrating two-phase liquid and vapour ( $L+V)$ fluid inclusion and monophase liquid trapped in barite; b) Fluid inclusions of twophase liquid and vapour ( $(\mathrm{L}+\mathrm{V})$ and monophase liquid $(\mathrm{L})$ and vapour $(\mathrm{V})$; $\mathrm{c}$ ) linear arrangement of fluid inclusions; $\mathrm{d})$ Necking down in fluid inclusion hosted in barite in the Duna mine. 
Table 5. Comparison of the mineralization characteristics of the Duna mine with Irish-type and MVT deposits from Robb (2005), SHAHABPOUR (2010) and BODNAR et al. (2014).

\begin{tabular}{|c|c|c|c|}
\hline Specification & Duna mine & Irish-type & MVT \\
\hline Host Rock & Dolomitic Limestone & Dolomitic Limestone & Dolomite and Sand \\
\hline Fluid inclusion (temperature) & $106-285^{\circ} \mathrm{C}$ & $150-240^{\circ} \mathrm{C}$ & $75^{\circ} \mathrm{C}-200^{\circ} \mathrm{C}$ \\
\hline $\mathrm{NaCl}$ wt.\% eq. & $7.34-23.76 \%$ & $10-23 \%(<15 \%)$ & $10-30 \%$ \\
\hline Form of Reserve & Stratabound & Stratabound and Stratiform & Stratabound \\
\hline Ore Mineralogy & $\mathrm{Pb}, \mathrm{Zn}, \mathrm{Ag}, \mathrm{Ba}, \mathrm{Fe}, \mathrm{Cu}$ & $\mathrm{Pb}, \mathrm{Zn}, \mathrm{Ag}, \mathrm{Cu}, \mathrm{Fe}$ & $\mathrm{Pb}, \mathrm{Zn}, \mathrm{Cd}, \mathrm{Ge}$ \\
\hline Ore and Gangue type & $\begin{array}{l}\text { Galena, Sphalerite, Barite, } \\
\text { Chalcopyrite, Tetrahedrite }\end{array}$ & $\begin{array}{l}\text { Galena, Sphalerite, Barite, } \\
\text { Chalcopyrite, Tetrahedrite }\end{array}$ & $\begin{array}{l}\text { Galena,Sphalerite, Barite, } \\
\text { Fluorite }\end{array}$ \\
\hline Syngenetic and Epigenetic & Epigenetic & Epigenetic and Syngenetic & Epigenetic \\
\hline $\begin{array}{l}\text { Geologic Relationship } \\
\text { and Host Rock }\end{array}$ & $\begin{array}{l}\text { Disseminated, Bedded, } \\
\text { Fracture infilling, Replacement }\end{array}$ & $\begin{array}{l}\text { Disseminated, Bedded, } \\
\text { Open space infilling }\end{array}$ & $\begin{array}{l}\text { Fracture infilling, } \\
\text { Replacement }\end{array}$ \\
\hline Magmatism & Basaltic volcanic and subvolconic rock & Basaltic magma activity & $\begin{array}{c}\text { Usually nonexistence, mafic } \\
\text { and alkali magma }\end{array}$ \\
\hline Alteration & Dolomitic and siliceous & Dolomitic and siliceous & Dolomitic and siliceous \\
\hline $\mathrm{Zn} / \mathrm{Zn}+\mathrm{Pb}$ & $0.002-0.1$ & $0.6-0.8$ & $0.6-0.8$ \\
\hline Geological and Tectonic setting & $\begin{array}{c}\text { Shallow marginal seas, rift basins } \\
\text { Palaeozoic }\end{array}$ & Shallow marginal seas, rift basins & Marginal basin, rift, carbanate platform \\
\hline Timing of Mineralization & Palaeozoic & Mostly in Palaeozoic & Mostly in Palaeozoic \\
\hline
\end{tabular}

of $-34{ }^{\circ} \mathrm{C}$ to $-18{ }^{\circ} \mathrm{C}$. The last ice melting temperature $\left(\mathrm{Tm}_{\text {ice }}\right)$ of the inclusions ranged from $-23.5^{\circ} \mathrm{C}$ to $-4.3^{\circ} \mathrm{C}$ (average $-15.42^{\circ} \mathrm{C}$ ).

All inclusions in barite from the second stage/younger/Irishtype of mineralization homogenized between $113{ }^{\circ} \mathrm{C}$ to $285^{\circ} \mathrm{C}$ (average $197.63^{\circ} \mathrm{C}$ ). Based on Fig. 11a, most of the fluid inclusions are homogenized in the range of $150-250^{\circ} \mathrm{C}$ (mostly $210^{\circ} \mathrm{C}$ ), and a small number are homogenized in the range of $260-280^{\circ} \mathrm{C}$ from the discordant layers. This high homogenization temperature in barite seems to be acceptable due to the lack of leakage and bursting in the inclusions. To ensure the absence of leakage in fluid inclusions, a thermometer test was performed with great care. The argued $\mathrm{H}_{2} \mathrm{O}$ leakage from originally water rich fluid inclusions, may result in extremely gas-rich fluid inclusions (BAKKER \& JANSEN, 1990).

The salinity of fluid inclusions $(\mathrm{NaCl}+\mathrm{CaCl} 2$ wt. \%) in two studied sections, ranged from 7.34-22.76 wt. \% $\mathrm{NaCl}$ equivalent (average 18.90 wt. \% $\mathrm{NaCl}$ equivalent) in second stage/younger/ Irish-type of mineralization (Fig. 11b). According to these salinity values, the Duna mine's ore-forming fluids were high-salinity fluids.

\section{DISCUSSION}

\subsection{Origin of metals, fluids, and the mineralization type}

Lead mineralization in the Alborz zone attributed to the orogenic events that went on the Alborz zone after the Cretaceous period and accompanied by tectonic events and crustal thickening which led to the migration of lead from the old sources (Mesozoic and Cenozoic periods) and eventually mineralization in the younger rock units (MIRNEJAD et al., 2015). Previous studies in the field of economic geology and ore genesis over the Duna mine have suggested diverse origins for the lead mineralization which include: a product of epithermal to mesothermal mineralizing process simultaneous with activity of submarine hydrothermal fluids (HOLZER \& MOMENZADEH, 1969; SAMANI RAD, 1999), a magmatic source for the mineralizing fluids (SAMANI-RAD, 1999), Permian volcanogenic origin (HOLZER \& MOMENZADEH, 1969), a Mississippi Valley-type (MVT) ore deposit (YAGHOOB POOR, 2004), SEDEX (BAZARGANI-GUILANI, 1982), and a skarn type, or the Tertiary magmatic activity related (HASSANZADEH et al., 2002; NEKOUVAGHT TAK et al., 2009).

The present study, according to the following evidence, shows that the mineralization in the Duna mine includes two major mineralization phases; $1^{\text {st }}$ stage/older/MVT (mostly concordant layers) overprinted by a second stage/younger/Irish-type (mostly discordant layers).

Comparison of the characteristics of the Duna mine with the MVT and Irish-type deposits (Table 5), shows similarities with these mineralization types such as host rock, form of mineralization, epigenetic nature, alteration types, $\mathrm{Zn} /(\mathrm{Zn}+\mathrm{Pb})$ ratio, and geological and tectonic settings (ROBB, 2005; SHAHABPOUR, 2010). In terms of some features, such as homogenization tem-
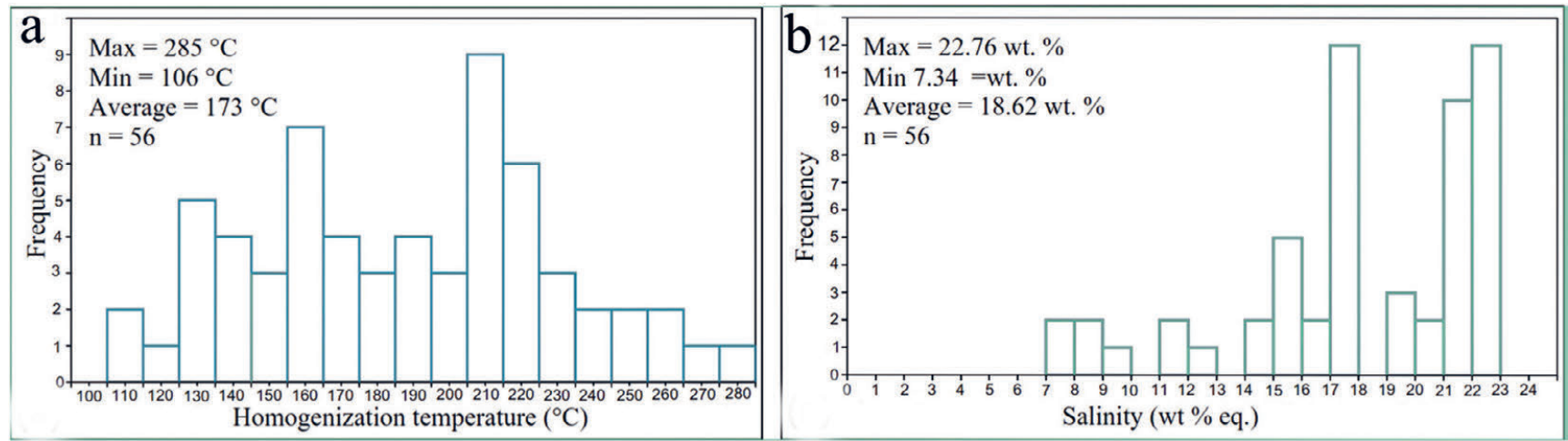

Figure 11. Histograms showing frequency of distribution of homogenization temperature (Th) and salinity (wt \% NaCl eq.) for fluid inclusions of barite from concordant and discordant layers in the Duna mine. 


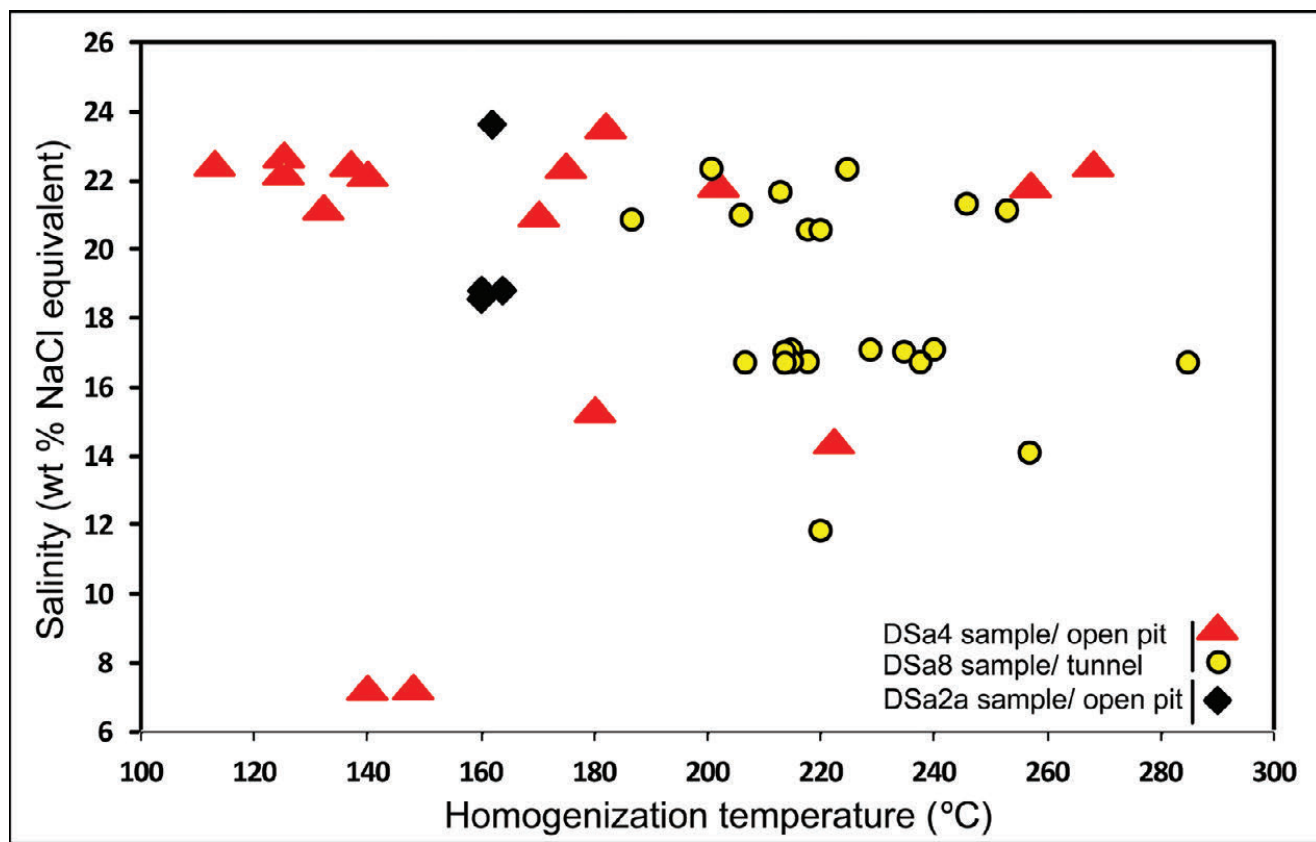

Figure 12. Homogenization temperature-salinity plot for fluid inclusions from ore samples of concordant veins/ $1^{\text {st }}$ stage/older/MVT (DSa2a), and second stage/ younger/lrish-type (DSa4 and DSa8) in the Duna mine.

perature of fluid inclusions, presence of high Ag and other trace elements in the ore samples, mineralogy and gangue, in most discordant layers the Duna $\mathrm{Pb}-\mathrm{Ba}-(\mathrm{Ag})$ mine is comparable to the Irish-type deposit. Fluorite is usually present in MVT deposits while it is rarely reported in Irish-type deposits (GIZE \& BARNES, 1987). The concentration of some trace elements such as $\mathrm{Cu}, \mathrm{As}$, and $\mathrm{Sb}$ in the Duna mine is similar to the Irish-type and magmatic Pb-Zn deposits (LEACH et al., 2005).

The high amount of Mg (3.6 wt. \%) in the host rock of the Duna $\mathrm{Pb}-\mathrm{Ba}-\mathrm{Ag})$ mine indicates its high dolomite content formed locally, while the change in its colour from gray to brown was due to its high iron content (8.8 wt. \%). The evidence of dolomitization is the high $\mathrm{Mg}$ content and the low $\mathrm{Ca} / \mathrm{Mg}$ ratio (PLUMLEE et al., 1994) as well as the reaction between the mineralized fluid and carbonate host rock. In the Duna mine, lead has a higher enrichment than zinc, and $\mathrm{Zn} /(\mathrm{Zn}+\mathrm{Pb})$ ratio is lower than 0.1 , which is comparable to MVT and Irish-type deposits. According to Table 1, it seems that the average amount of lead (18.5 $\%$ ) in both discordant and concordant veins is approximately equal. After lead, silver is the second economically important element in the Duna mine.

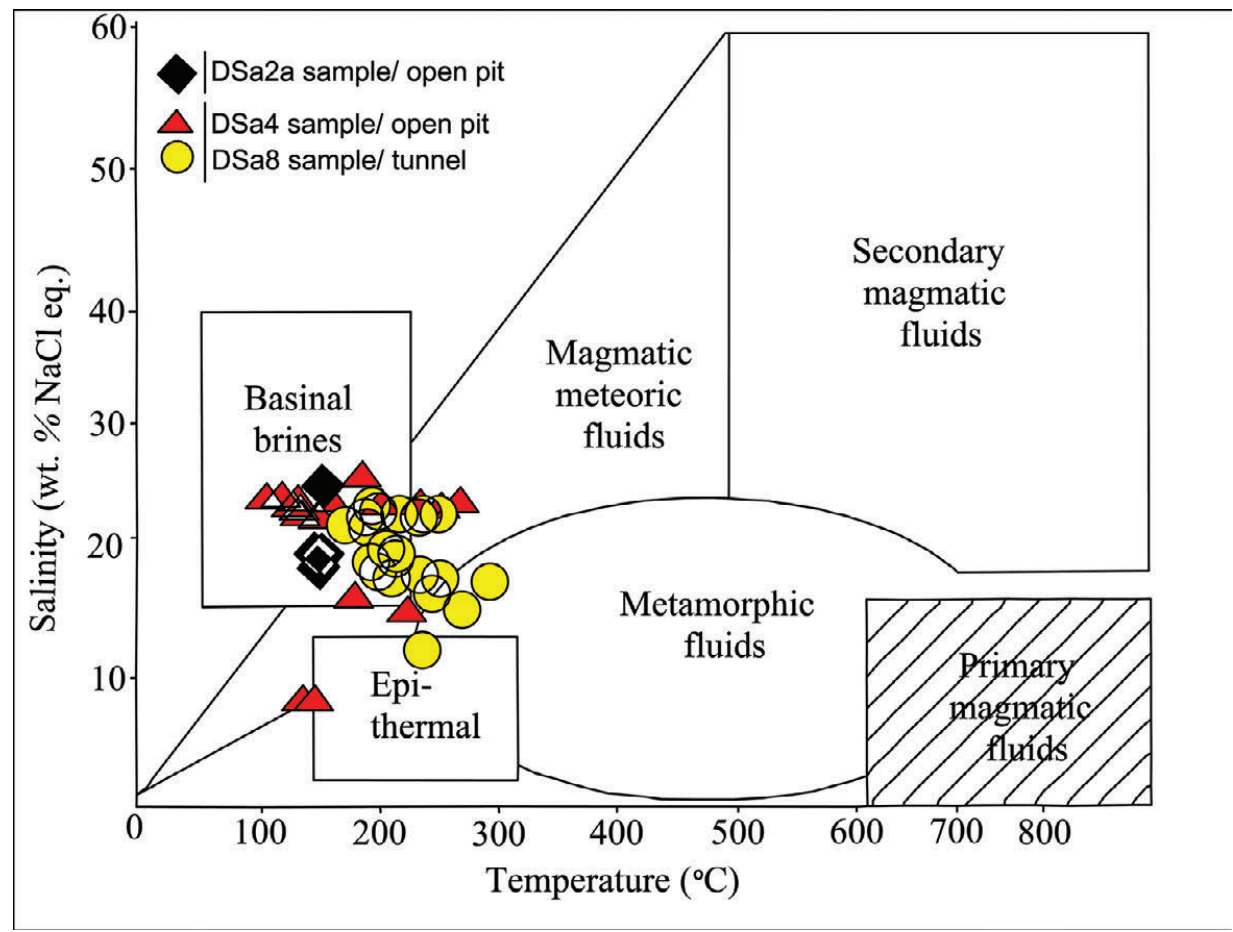

Figure 13. A homogenization temperature-salinity diagram (BEAN, 1983) for ore-bearing fluids from open pit/1 ${ }^{\text {st }}$ stage/older/MVT (DSa2a), and discordant veins/ second stage/younger/Irish-type (DSa4 and DSa8) in the Duna mine. 
The silver content of the $\mathrm{Pb}-\mathrm{Zn}$ deposits in relation to magmatic deposits is usually more than $1000 \mathrm{ppm}$ and up to 5000 ppm while less than 500 ppm in sedimentary deposits (QIAN, 1987; NEJADHADAD et al., 2015). Silver content in the Duna mine ranges from 18.9-264.3 ppm (average $120.4 \mathrm{ppm}$ ) in the open pit (mostly concordant layers; $1^{\text {st }}$ stage/older/MVT) while it ranges from 9 to 7030 ppm (average $1553 \mathrm{ppm}$ ) in the tunnels (mostly discordant layers; second stage/younger/Irish-type), according to a 45 mineral chemistry analysis by the Damavand Mining Company (2013). This indicates a change in the mineralization conditions or differences in the type of ore-forming fluids. Paragenesis of high temperature minerals such as pyrite and chalcopyrite and co-precipitation of sphalerite and chalcopyrite (Fig. 5a) indicates high temperature of the mineralizing fluids (BORTNIKOV et al., 1991). The high content of Ag, $\mathrm{Cu}, \mathrm{As}$, and $\mathrm{Sb}$ in the Duna mine which is associated with the second stage/younger/Irish-type of mineralization is also very similar to the $\mathrm{Pb}-\mathrm{Zn}$ deposits associated with magmatic activities (LEACH et al., 2005).

The chondrite-normalized REE patterns of the mineralized host rock show a negative $\mathrm{Ce}$ anomaly and positive Eu anomaly. The positive anomaly of Eu and the weak anomaly of Ce correspond to the pattern of a magmatic fluid (KATO, 1999). The mineralized host rock indicates differences in $\Sigma$ REE, negative Ce, and positive Eu compared to the unmineralized host rock, the igneous rocks, and the Akapol intrusive mass. This may be indicative of a difference in the REE source in the mineralized rocks and unmineralized rocks. The Eu positive anomaly in sample Dsa17 from the discordant/second stage/younger/Irish-type is different and higher than the other samples. The REE patterns of the mineralized host rock show an irregularity and heterogeneity that can result from the mixing of magmatic fluids with basin and atmospheric waters (KATO, 1999).

The significant salinity variations, are most likely to be controlled by different origins and fluid mixing. Salinity of fluid inclusions of concordant/ $1^{\text {st }}$ stage/older/ MVT (sample DSa2b) with the range of 18.54 to 23.65 (average 19.92) wt. \% $\mathrm{NaCl}$ equivalent and a homogenization temperature of $135-165^{\circ} \mathrm{C}$ in the Duna $\mathrm{Pb}$ -
$\mathrm{Ba}-(\mathrm{Ag})$ mine revealed that the ore-forming fluids were of lowtemperature, high-salinity $\mathrm{H} 2 \mathrm{O}-\mathrm{NaCl}$ system fluids. The results of fluid inclusion analyses in discordant/second stage/younger/ Irish-type (samples DSa4 and DSa8) demonstrate a wide salinity range of 7.34 to $22.76 \mathrm{wt}$. \% $\mathrm{NaCl}$ equivalent and a homogenization temperature of $105-285{ }^{\circ} \mathrm{C}$. These fluid inclusions can be subdivided into three groups: a low-salinity with average $7.34 \mathrm{wt}$. $\% \mathrm{NaCl}$ equivalent, an intermediate-salinity with 11.78 to 17.1 (average 16.04) wt. \% $\mathrm{NaCl}$ equivalent, and a high-salinity with 20.55 to 23.65 (average 21.76) wt. \% $\mathrm{NaCl}$ equivalent. This variety of salinity values can be due to the different origins of fluids or combinations of several fluid types through factors such as isothermal mixing, heating depressurization, and surface fluid dilution. The homogenization temperature of fluid inclusion in MVT deposits ranges from 75 to $175^{\circ} \mathrm{C}$, while salinities are about $20 \pm 5$ wt. $\% \mathrm{NaCl}$ equivalent (BODNAR et al., 2014). It seems that fluid inclusions of concordant veins at temperatures about $155-165{ }^{\circ} \mathrm{C}$ were formed in the $1^{\text {st }}$ stage/older/MVT of mineralization, while fluid inclusions of discordant mineralized veins, were mostly formed in the second stage/younger/Irish-type of mineralization, entrapped in temperatures between $113-285^{\circ} \mathrm{C}$. This may indicate different formation conditions of the discordant mineralized veins compared to the concordant mineralized veins.

There is no correlation between homogenization temperature and salinity (Fig. 12), but high-salinity and high homogenization temperature values of inclusions suggests that some magmatic and meteoric fluids were mixed (ARRIBAS et al., 1995). Rapid precipitation of sulfides, may have been driven by mixing between brines and higher temperature metal-bearing fluids derived from a basement-equilibrated fluid reservoir (WILKINSON \& EYRE, 2005) and/or at least spatially with igneous intrusions and saline springs (BANKS et al., 2002). The homogenization temperature-salinity diagram for ore-bearing fluids (BEANE, 1983), indicates the involvement of basin brine fluids in concordant veins (DSa2a), and magmatic-meteoric fluids in discordant veins (DSa4 and DSa8) in the Duna mine (Fig. 13). A compilation of $\mathrm{T}_{\mathrm{h}}$-Salinity information from different deposit types (ROEDDER, 1984), indicates that ore-forming fluids in the Duna mine (Fig. 14),

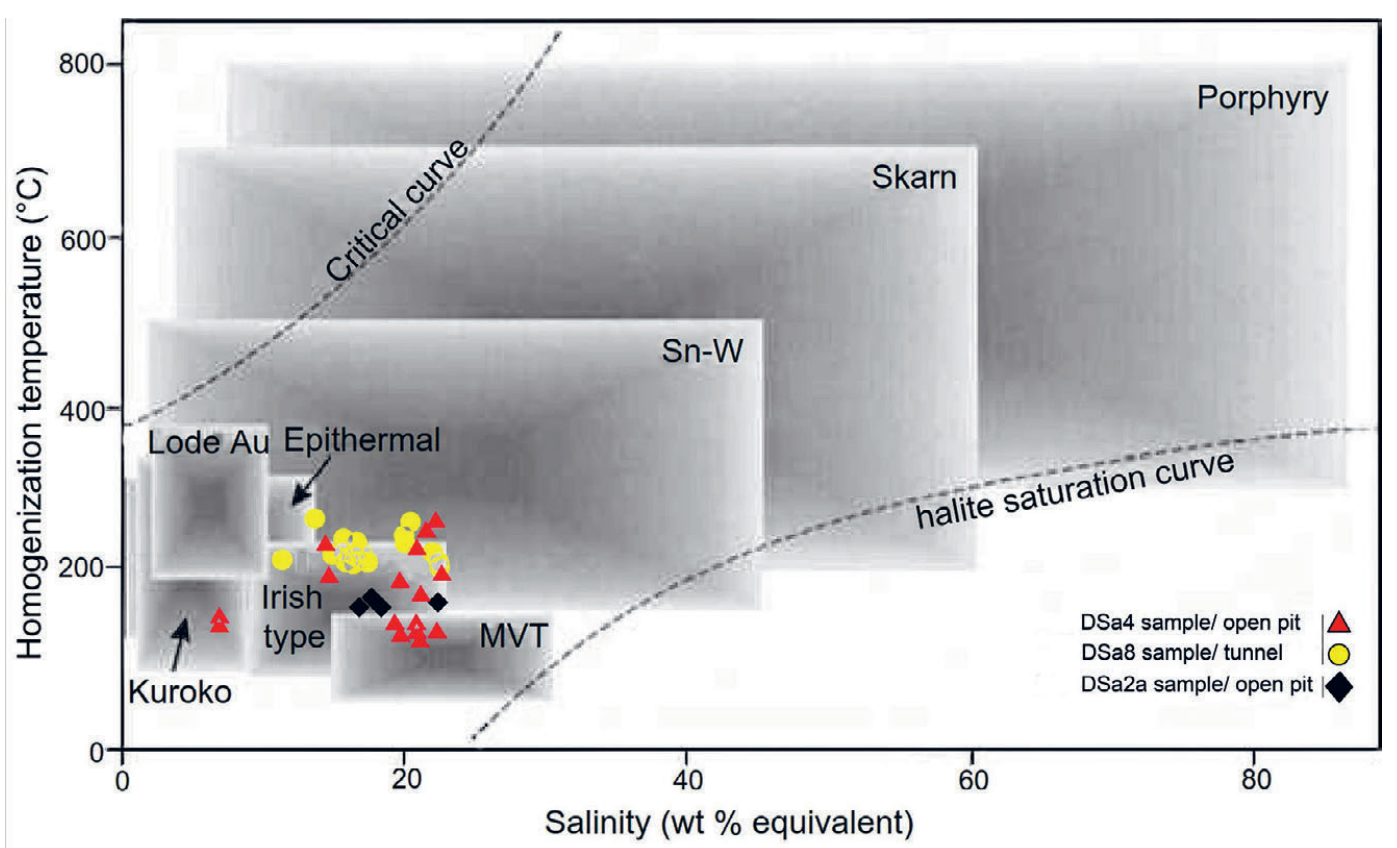

Figure 14. Homogenization temperature-salinity plot for fluid inclusions (ROEDDER, 1984) from an ore sample of the open pit and massive barite of tunnel for MVT (DSa2a), and Irish-type (DSa4 and DSa8) of mineralization in the Duna mine. 


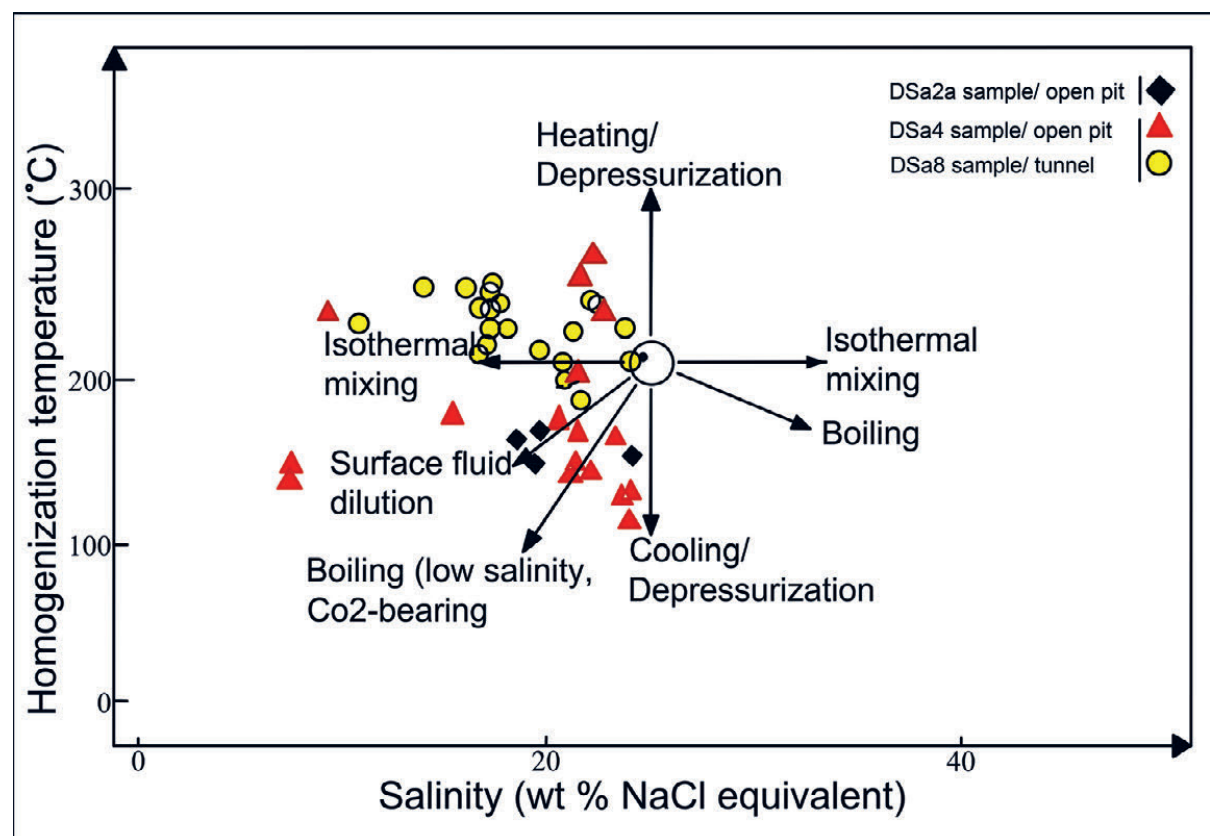

Figure 15. A schematic diagram showing typical trends in homogenization temperature-salinity space due to various fluid evolution processes (WILKINSON, 2001) and the position of ore-bearing fluids for MVT (DSa2a/open pit), and Irish-type (DSa4/open pit and DSa8/tunnel) of mineralization in the Duna mine.

have a proximity to an MVT deposit (mostly concordant/DSa2a), and Irish-type ore deposits (mostly discordant/DSa4 and DSa8). Variation in the last ice melting temperature of the fluid inclusions can be the result of variation in the salinity content of the multiple fluid sources and fluid mixing. The various fluid evolution processes on the $\mathrm{T}_{\mathrm{h}}$-salinity bivariate plot (WILKINSON, 2001), show that the surface fluid dilution in $1^{\text {st }}$ stage /older/MVT, and surface fluid dilution, isothermal mixing, and ultimately cooling processes of the ore-forming fluids occurred in second stage/younger/Irish-type of mineralization in the Duna mine (Fig. 15). The process of cooling and dilution could be the main reason for deposition.

The study of the $\mathrm{Pb}-\mathrm{Zn}$ mining areas in Ireland (Silvermine, Tynagh, Lisheen, Navan and Keel deposits), shows that a large flow of fluids, at a depth of about $6 \mathrm{~km}$ in the northern part of this mining area (Navan، Keel and Tynagh deposits), supplies a fluid temperature of about $200{ }^{\circ} \mathrm{C}$, while in the southern region (Silvermine and Lisheen deposits), the fluid temperature is about 300 ${ }^{\circ} \mathrm{C}$, which is the result of the influence of a mafic intrusive mass (WILKINSON \& HITZMAN, 2015). The microthermometry of fluid inclusions in the barite host from the Silvermine deposit shows that the salinities range from 8 to 28 equivalent wt. $\%$ $\mathrm{NaCl}$, while the homogenization temperatures range from 50 to $260{ }^{\circ} \mathrm{C}$ (SAMSON and RUSSELL, 1987). Therefore, according to the study of the fluid inclusions, the second stage of the Duna mine can be comparable to the Silvermine and Lisheen deposits of the Irish midlands basin.

According to the isotopic ratios, ${ }^{206} \mathrm{~Pb} /{ }^{204} \mathrm{~Pb},{ }^{207} \mathrm{~Pb} /{ }^{204} \mathrm{~Pb}$, ${ }^{208} \mathrm{~Pb} /{ }^{204} \mathrm{~Pb},{ }^{238} \mathrm{U} /{ }^{204} \mathrm{~Pb}$, the mineralization age of the Duna mine constrained to $\sim 50 \pm 6$ Ma (MIRNEJAD et al., 2015), which is nearly synchronous with the intrusion of the Akapol granitoid which is equal to $54 \pm 4$ to $56 \pm 3$ Ma measured by $A r^{40}-A r^{39}$ and $U-P b$ (AXEN et al., 2001b) and represents the second stage/ younger/Irish-type of mineralization. The most important role of the Akapol intrusive mass has been as a heat source for the oreforming fluids. Therefore, the Akapol granitoid intrusive mass has played an influential role in the second stage/younger/Irish- type of mineralization in the Duna mine and can be compared to the mafic intrusive bodies in the Silvermine and Lisheen deposits in Ireland.

\subsection{Genetic model}

The discordant mineralized samples in the Permian dolomitic carbonate host rock of the Duna $\mathrm{Pb}-\mathrm{Ba}-(\mathrm{Ag})$ mine are comparable to an epigenetic mineralization. Samples collected from the concordant layers which indicate simple mineralogy and low Ag, Sb, and $\mathrm{Cu}$ content are consistent with MVT deposits (DILL et al., 2011). The study of fluid inclusions in the concordant $/ 1^{\text {st }}$ stage shows that the salinity and $\mathrm{Th}(18.54-23.65 \mathrm{wt} \% \mathrm{NaCl}$ equivalent, $135-165^{\circ} \mathrm{C}$ ) is compatible with the salinity and Th range of MVT ore fluids (10-30 wt \% NaCl equivalent, $75-200^{\circ} \mathrm{C}$ ). These high-salinity fluids could have been derived from the evaporation of seawater and the precipitated halite (BANKS et al., 2002). Since barite accompanies galena in the Duna mine, the high salinity and metal rich fluids could have influenced this type of occurrence in the $1^{\text {st }}$ stage/older/MVT of mineralization. In the northern Alborz, including the study area, three intense deformation phases occurred after the Jurassic, especially during the Late Cretaceous, Eocene-Oligocene, and Pliocene (AXEN et al., 2001b; ALLEN et al., 2003; GUEST et al., 2006; HAKIMI ASIABAR \& BAGHERIAN, 2018). The Early Cimmerian orogenic movements in the Alborz mountain range caused an angular unconformity between the Jurassic and Triassic rock units. This could be a major reason for the evolving stratabound and stratiform Permian-hosted $1^{\text {st }}$ stage/older/MVT mineralization in the Duna mine.

A schematic overview of the genetic model of the Duna PbBa-(Ag) mine (Fig. 16) with respect to the geological and tectonic sections of the northern Alborz (Fig. 16a), shows that the late Cretaceous-Tertiary tectonic conditions have caused uplift, folding, first generations of faults (W-E direction), and inversion tectonics style of deformation along previous normal faults which in turn generated numerous north and south verging thrust faults (AXEN et al., 2001b; ALLEN et al., 2003; FURSICH et al., 2005; 


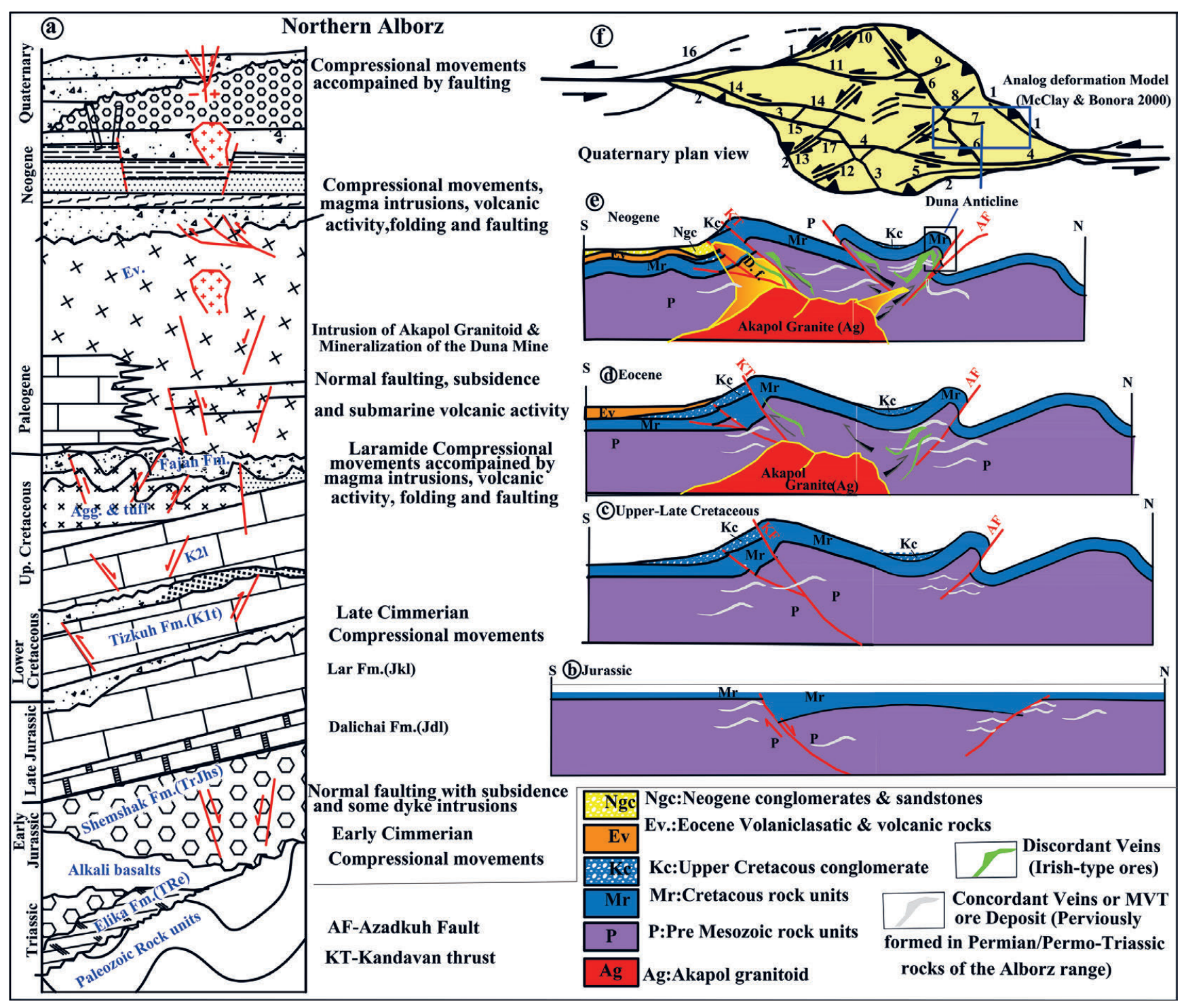

Figure 16. Schematic model of the genesis of the Duna Pb-Ba-(Ag) mine. a) The tectonostratigraphic chart (modified after Hakimi Asiabar and Bagheryian, 2018) of the northern Alborz range; $b, c, d, e)$ Schematic model for the formation processes of faults and folding, Akapol intrusive; $f$ ) Analog deformation model (MC CLAY and BONORA, 2000).

GUEST et al., 2006). In the structural units within the study area (Fig. 16b, c) these faults are the result of the formation of the Duna anticline due to the Laramide orogeny. In the Eocene, another extensional event occurred with subsidence and remarkable eruptions in the Alborz range, with some magma intrusions, which continued with a compression event of the Late Eocene- Oligocene. The Pyrenean orogeny, in addition to generating secondgeneration faults (WSW-ENE directions), caused the intrusion of large masses in the northern Alborz, such as the Akapol intrusive mass at a distance of $4 \mathrm{~km}$ south of the Duna mine.

The discordant mineralization in the Duna mine is more compatible with the high content of $\mathrm{Ag}, \mathrm{Sb}, \mathrm{Cu}$, As and $\mathrm{Sr}$ in the Irish-type deposits than in the MVT deposits. The ore mineralization in the Duna mine is enriched in $\mathrm{Pb}$ compared to $\mathrm{Zn}$. The salinity and Th of the Duna mine ore fluids (7.34-22.76 wt \% $\mathrm{NaCl}$ equivalent, $113-285^{\circ} \mathrm{C}$ ) are more comparable to the salinity and Th of ore fluids in the Silvermine deposit of the Irish Midlands basin $\left(8-28\right.$ wt. $\% \mathrm{NaCl}$ equivalent, $50-260{ }^{\circ} \mathrm{C} /$ or $\left.300{ }^{\circ} \mathrm{C}\right)$ in the host rock barite (SAMSON \&RUSSELL, 1987). In general, fluid inclusion studies on the second stage show that two fluids with different Th but similar high salinity were mixed during mineralization. One of the fluids that had high salinity and high Th, was probably metal-rich and has been affected by the intrusive mass of Akapol. The tectonic movements and activities related to the Akapol intrusive mass in the late Paleocene to Early Eocene of the region (Fig. 16d, e), resulted in faulting or dilatation along the main structural patterns as well as an increase in temperature and a pressure drop in the crust. This was often associated with deformation in the tectonic motions of this period, fluid motion, and occurrence of hydrothermal breccia (HAKIMI ASIABAR \& BAGHERIAN, 2018). Therefore, the ore-bearing elements have been washed out from their original location and deposited as veins and veinlets along strike-slip faults and in open spaces. This happened in the core of the anticline under appropriate physicochemical conditions in the first and second generation of faults as the feeding zones of the fluid flow. Thus the second stage/younger/Irish-type was formed as a result of the Cenozoic orogenic phases with the intrusion of plutonic bodies such as the Akapol intrusive mass (mostly discordant layers) which impacts on the $1^{\text {st }}$ stage/older/MVT ore deposit (mostly concordant layers). 


\section{CONCLUSION}

The study of geology, mineralogy, geochemistry and fluid inclusion in the Duna Pb-Ba-(Ag) mine indicates the occurrence of two stages of mineralization. The epigenetic Duna mineralization occurs at the core of an anticline, controlled by faults, and chemically affected by bituminous layers, dolomitic horizons, and impermeable volcanic rocks of the Permian. Microscopic and field investigations of concordant and discordant ore samples indicate that they consist mainly of galena and minerals such as sphalerite, tetrahedrite, pyrite, and chalcopyrite. Barite, dolomite, calcite, and quartz are the gangue minerals. Supergene minerals include Feoxides, covellite, cerussite, anglesite, malachite and azurite. Texture evidence shows that the ore bodies mostly filled structural open-spaces of the dolomitic host rock. Mineralogy, texture, and paragenesis of the concordant mineralization are more comparable to MVT deposits, while the evidence such as paragenesis of minerals formed at high temperature e.g. pyrite and chalcopyrite as well as co-precipitation of sphalerite and chalcopyrite in discordant mineralization is mostly comparable to Irish-type deposits.

Geochemical analysis of discordant mineralization layers shows enrichment of Ag (146.6 ppm), As (1132.7 ppm), Cu (14310 ppm), Sb (3875 ppm), and Sr (9200 ppm) compared to mineralized concordant layers which is comparable to Irish-type deposits. Salinity of fluid inclusions of concordant layers has a range of 18.54 to $23.65 \mathrm{wt}$. \% $\mathrm{NaCl}$ equivalent and a homogenization temperature of $135-165{ }^{\circ} \mathrm{C}$ which is comparable to MVT deposits, while the discordant layers with a wide salinity range from 7.34 to $22.76 \mathrm{wt}$. $\% \mathrm{NaCl}$ equivalent and the high homogenization temperature of 105 to $285^{\circ} \mathrm{C}$ are comparable to Irish-type deposits.

The aforementioned evidence together with the tectonic setting and the structural units, positive anomalies of Eu/Eu*, noncompliance of REE pattern of mineralized samples with the surrounding rocks, and simultaneous formation of the Duna mine (50 $\pm 6 \mathrm{Ma} / \mathrm{MIRNEJAD}$ et al., 2015) and the Akapol granitoidic intrusive body ( $54 \pm 4$ to $56 \pm 3 \mathrm{Ma} / \mathrm{AXEN}$ et al., 2001b) suggest the occurrence of two stage of mineralization in Duna namely the concordant $/ 1^{\text {st }}$ stage/older/MVT, and the discordant/second stage/younger/Irish-type. The Early Cimmerian orogenic movements in the Alborz mountain range created an angular unconformity between the Jurassic and Triassic rock units, and it could have been a good reason for the evolving stratabound and stratiform Permian-hosted $1^{\text {st }}$ stage/older/MVT deposits. The occurrence of the second stage/younger/Irish-type deposit is the result of the Laramide orogenic movements. The mixing of two mineralizations in the second stage (overprint) as a result of the effect of magmatic fluid has made it impossible to determine the type of ore deposit in the Duna mine. The second stage/younger/Irishtype deposit is comparable to the Silvermine and Lisheen deposits in the Pb-Zn mining area in Ireland.

\section{ACKNOWLEDGMENT}

This project was supported by the Damavand Mining Company. We would like to thank Mr. Amin AKRAMI and Mr. Arash MIRSHAHI who were the chief executives of the Damavand Mining project and supported us with sharing their information. We would also like to thank two anonymous reviewers for their very constructive suggestions and comments.

\section{REFERENCES}

AGHANABATI, A. (2004): Geology of Iran.- Geological Survey of Iran Publication. Tehran, $733 \mathrm{p}$.

ALAVI, M. (1991): Tectonic map of the Middle East (scale 1:5.000.000).- Geological Survey and Mineral Exploration of Iran, Tehran.
ALLEN, M., GHASSEMI, M.R., SHAHRABI, M. \& QORASHI, M. (2003): Accommodation of late Cenozoic oblique shortening in the Alborz range, northern Iran.J. Structural. Geol., 25, 659-672. doi.org/10.1016.s0191-8141 (02) 00064-0

ANNELLS, R.N. (1975): Explanatory text of the Qazvin and Rasht quadrangles map.Geological Survey of Iran, E3 and E4, 94 p.

ARRIBAS, A.J.R., CUNNINGHAM, C.G., RYTUBA, J.J., RYE, R.O., KELLY, C., PODWYSOCKI, M.H., McKEE, E. H. \& TOSDAL, R. M. (1995): Geology, geochronology, fluid inclusions and isotope geochemistry of the Rodalquilar Au alunite deposits, Spain.- Economic Geology, 90, 795-822.

AXEN, G.J., STOCKLI, D.F., LAM, P., GUEST, B. \& HASSANZADEH, J. (2001b): Implications of preliminary (U-Th/He cooling ages from the central Alborz Mountains, Iran.- Geological Society of America, Abstracts with Programs., 33, 257 p.

BAHARFIRUZI, K.H. \& SHAFEII, A.R. (2005): Geological map of Javaherdeh sheet.Geological Survey of Iran 1:100.000.

BAKKER, R.J. \& JANSEN, B.H. (1990): Preferential water leakage from fluid inclusions by means of mobile dislocation.-Nature, 345, 58-60. doi: 10.1038/345058a0

BANKS, D.A., BOYCE, A.J. \& SAMSON, I.M. (2002): Constraints on the Origins of Fluids Forming Irish Zn-Pb-Ba Deposits: Evidence from the Composition of Fluid Inclusions.- Economic Geology, 97, 471-480. doi: 10.2113/gsecongeo.97.3.471

BAZARGANI-GILANI, K. (1982): Die mittelpermischen Scichtgebundenen Blei-ZinkSchwerspat- Largestattendes Kalawanga Distriktes. Zentral Alborz, Iran (mit besonderer Berucksichtigung des Duna-Grubenfelds).- Diss univ. Heidelberg.

BEAN, R.E. (1983): The magmatic-Meteoric Transition.-Geothermal resources council, special report, 13, 245-253.

BERBERIAN, M. \& KING, G.C.P. (1981): Towards a Paleogeography and Tectonic Evolution of Iran.- Can J Earth Sci, 8, 210-265. doi: 10.1139/e81-019

BODNAR, R.J., LECUMBERRI-SANCHEZ, P., MONCADA, D. \& STEELE-MACLNNIS, S. (2014): Fluid inclusions in hydrothermal ore deposits.- In: HOLLAND, H.D. and TUREKIAN, K.K. (eds.): Treatise on Geochemistry, vol 133. Oxford, Elsevier, 119-142. doi: 10.1016/B978-0-08-095975-7.01105-0

BOYNTON, W.V.(1984): Cosmochemistry of the rare earth elements; meteorite studies.In: HENDERSON, P., (ed.): Rare Earth Element Geochemistry. Amsterdam and New York, Elsevier Science, 63-114. doi.org/10.1016/B978-0-444-421487.50008-3

BORTNIKOV, N.S., GENKIN, A.D., DOBROVOl'SKAYA, M.G., MURAVITSKAYA, G.N. \& FILIMONVA, A.A. (1991): The Nature of Chalcopyrite Inclusions in sphalerite: Exsolution, Coprecipitation, or "Disease"? - Economic geology, 86/5, 1070-1082. doi: 10.2113/gsecongeo.86.5.1070

DAVIDHEISER-KROLL, B.J. (2014): Understanding the fluid pathways that control the Navan Ore body.- Ph. D. Thesis. University of Glasgow, Scotland.

DILL, H.G., WEISS, W, BOTZ, R. \& DOHRMANN, R. (2011): Paleontological, mineralogical and chemical studies of syn genetic and epigenetic $\mathrm{Pb}-\mathrm{Zn}$-Ba-P mineralization at the stratotype of the K/P boundary (El kef area, Tunisia).- Int J Earth Sci, 100, 805-846. doi: 10.1007/s00531-010-0517-2

FURSICH, F.T., WILMSEN, M., SEYED-EMAMI, K., CECCA, F. \& MAJIDIFARD, M. R. (2005): The upper Shemshak Formation (Toarcian-Aalenian) of the Eastern Alborz (Iran): Biota and palaeo environments during a transgressive-regressive cycles.-Facies, 51, 379-398. doi: 10.1007/s10347-005-0051-z

GHORBANI, M., (2013): The Economic Geology of Iran Mineral deposits and natural resources.- Springer, 569 p. doi:10.1007/978-94-007-5625-0

GIZE, A.P. \& BARNES, H.L. (1987): The organic geochemistry of two Mississippi valley-type lead-zinc deposits.- Economic Geology, 82/2, 457-470. Doi: 10.2113/ gsecongeo.82.2.457

GOODFELLOW, W. \& LYDON, J. (2007): SEDEX deposits.- Geological Survey of Canada, $16 \mathrm{p}$.

GOLDSTEIN, R.H. \& REYNOLDS, T.J. (1994): Systematics of fluid inclusion in diagnostic minerals: SEPM short course 31.- Society for Sedimentary Geology, Tulsa OK, pp 199.

GOLONKA, J. (2004): Plate tectonic evolution of the southern margin of Eurasia in the Mesozoic and Cenozoic.- Tectonophysics., 381, 235-273. doi.org/10.1016/j.tecto.2002.06.004

GUEST, B., AXEN, G.J., LAM, P.S. \& HASSANZADEH, J. (2006): Late Cenozoic shortening in the west-central Alborz Mountain, northern Iran, by combined conjugate strike slip and thin-skinned deformation.- Geosphere., 2/1, 35-52. doi. org/10.1130/GES00019.1

HAKIMI ASIABAR, S. (2019): Structural deformations of the Duna mine area.- Journal of Earth Sciences.- Geological Survey \& Mineral Explorations of Iran, 28, $235-246$.

HAKIMI ASIABAR, S. \& BAGHERIYAN, S. (2018): Exhumation of the Deylaman fault trend and its effects on the deformation style of the western Alborz belt in Iran.- Int J Earth Sci (Geol Rundsch), 1-13. doi: 10.1007/s00531-017-1507-4

HASHEMIAN, E., JAMALI, H. \& AHMADIAN, J. (2018): Mineralogy, Fluid inclusion and Geochemistry of Tappeh-Khargosh Cu-Au deposit (SW of Ardestan), Iran.Journal of Economic geology, 10/2, 299-324.

HASSANZADEH, J., GHAZI, A.M., AXEN, G., GUEST, B., STOCKLIN, D. \& TUCKER, P. (2002): Oligocene mafic-alkaline magmatism in north and northwest of Iran: 
Evidence for the separation of the Alborz from the Urumieh-Dokhtar magmatic arc (abstract).- Geological Society of America, 34, $331 \mathrm{p}$.

HITZMAN, M.W. \& BEATY, D.W. (1997): The Irish Zn-Pb-(Ba) orefield.- In: SANGSTER, D.F. (ed.): Carbonate-hosted Lead-Zinc deposits. Society of Economic Geologists, Special Publication, 4, 112-143.

HOLZER, H.F. \& MOMENZADEH, M. (1969): Note on the geology of Elika and Duna lead mines, Central Alborz.- G.S.Iran, $14 \mathrm{p}$.

HORTON, B.K., HASSANZADEH, J., STOCKLI, D. F., AXEN, G. J., GILLIS, R. J., GUEST, B., AMINI, A.H., FAKHARI, M., ZAMANZADEH, S.M. \& GROVE, M. (2008): Detrital zircon provenance of Neoproterozoic to Cenozoic deposits in Iran: Implications for chronosrtatigraphy and collisional tectonics.- Tectonophysics, 451/1-4, 97-122. doi: 10.1016/j.tecto.2007. 11 .063

KATO, Y. (1999): Rare earth elements as an indicator to origins of skarn deposit: example of the Kamioka $\mathrm{Zn}-\mathrm{Pb}$ and Yoshiwara-Sonnatak $\mathrm{Cu}(-\mathrm{Fe})$ deposits in Japan.Resourse geology, 49/4, 183-198. doi: 10.1111/j.1751-3928.1999.tb00045.x

LEACH, D.L., \& SANGSTER, D.F. (1993): Mississippi Valley-type lead-zinc deposits.In: KIRKHAM, R.V., SINCLAIR W.D., THORPE R.I. \& DUKE, J.M. (eds.): Mineral Deposit Modeling. Geological Association of Canada Special Paper, 40, 289-314.

LEACH, D.L., SANGSTER, D.F., KELLEY, K.D., LARGE, R.R., GRAVEN, G., ALLEN, C.R., GUTZMER, J. \& WALTERS, S. (2005): Sediment-hosted Pb-Zn deposits: A global perspective.- In: HEDENQUIST, J.W. et al. (Eds.): One Hundredth Anniversary Volume. doi: 105382.AV100.18

MC CLAY, K. \& BONORA, M. (2000): Analog models of restraining stopovers in strikeslip fault systems.-AAPG Bulletin., 85/2, 233-260.

MC LENNAN, S.M. (1989): Rare earth elements in sedimentary rocks: Influence of provenance and sedimentary processes.- Reviews in Mineralogy, 21, 169-200.

MIRNEJAD, H., SIMONETTI. A. \& MOLASALEHI, F. (2015): Origin and formational history of some $\mathrm{Pb}-\mathrm{Zn}$ deposits from Alborz and Central Iran: $\mathrm{Pb}$ isotope constraints.- Int. Geol. Rev., 57, 463-471. doi:10.1080/00206814.2015.1013510

MODARESNIA, M., KHOSROTEHRANI, K., MOMENI, I. \& BABAZADEH, S.A. (2012): Upper Cretaceous planktonic foraminiferal biostratigraphy of East Dorfak area (Guilan - north of Iran).- Life Science Journal, 9/1, 242-253.

MONCADA, D., MUTCHLER, S., NIEBTO, A., REYNOLDS, T.J., RIMSTIDT, J.D. \& BODNAR, R.J. (2012): Mineral textures and fluid inclusion petrography of the epithermal Ag-Au deposits at Guanajuato, Mexico: Application to exploration.Journal of Geochemical Exploration, 114/12, 20-35. doi: 10.1016/j.gexplo.2011.12.001

NEJADHADAD, M., TAGHIPOUR, B., ZARASVANDI, A. \& KARIMZADEH, S.A. (2015): Geological, Geochemical and Fluid inclusion evidences for the origin of the Ravanj Pb-Ba-Ag deposit, north of Delijan city, Markazi Province, Iran.- Turkish J Earth Sci., 25, 179-200. doi:10.3906/yer-1501-26

NEKOUVAGHT TAK, M., BAZARGANI-GUILANI. K. \& FRAMARZI, M. (2009): Geology and Geochemistry of the lead-zinc carbonated hosted MVT mineralization in the north Semnan, Central Alborz., Iran.- In: Proccedings of $10^{\text {th }}$ biennial SGA Meeting Townsville, Economic Geology Research Unit, James Cook University, 499-501.

PARADIS, S., HANNIGAN, P. \& DEWING, K. (2007): Mississippi Valley-type leadzinc deposits.- In: GOODFELLOW, W.D. (ed.): Mineral Deposits of Canada: A Synthesis of Major Deposit-Types, District Metallogeny, the Evolution of Geological Provinces, and Exploration Methods. Geological Association of Canada, Mineral Deposits Division, Special Publication, 5, 185-203.
PASAND MAUSOUMI, j., GANJI, A., ANSARI, M. \& MODARRESNIA, M. (2001): Geochemical study of trace elements and REE in Pb-Zn Ore deposits, Kelardasht area (central area).- J Environment. Geol., 9/6, 58-63.

PLUMLEE, C.S., LEACH, D.I., HOFSTRA, A. H., LANDIS, G. P., ROWAN, E. L. \& VIETS, J. C. (1994): Chemical reaction path modeling of ore deposition in Mississippi Vally-type $\mathrm{Pb}$-Zn deposits of the Ozark region, U.S. midcontinent.-Econ Geol, 90/5, 1346-1349. doi.org/10.2113/gsecongeo.90.5.1346

QIAN, Z.H. (1987): Trace elements in Galena and Sphalerite and their geochemical significant in distinguishing the genetic types of $\mathrm{Pb}-\mathrm{Zn}$ deposits.- Geochemistry, 26, 177-190. doi.org/10.1007/BF02872218

ROBB, L.J. (2005): Introduction to Ore-forming procecces.- Blackewll Publishing Australia, $373 \mathrm{p}$.

ROEDDER, E. (1984): Fluid inclusions.- Reviews in Mineralogy, 12, 644.

SAJJADI NASAB, M., VOSOGHI ABEDINI, M., EMAMI, M. \& GHORBANI, M. (2000): Akapol Intrusive Mass Lithogenesis, Kelardasht Area, central Alborz, Iran. $-91 / 23,215-229$.

SAMANI RAD, S. (1999): Geology, mineralogy and genesis of Duna Pb deposit from Central Alborz.- M. Sc. Thesis, Islamic Azad University, North Tehran Branch, Iran.

SAMSON, L. M. \& RUSSELL, M.J. (1987): Genesis of the silvermines zinc-lead-barite deposit, Irland; fluid inclusion and stable isotope evidence.- Economic Geology., 82/2, 371-394. doi: 10.2113/gsecongeo.82.2.371

SHAHABPOUR, J. (2010): Feedback concept in the ore forming systems.- Resourse Geol., 60,109-115. Doi: 10.1111/j.1751-3928.2010.00118.x

SHEPHERD, T.J., RANKIN, A.H. \& ALDERTON, D.H.M. (1985): A practical guide to Fluid Inclusion Studies.- Blackie, The University of California, $239 \mathrm{p}$.

STEELE-MACINNIS, M., BODNAR, R.J. \& NADEN, J. (2011): Numerical model to determine the composition of $\mathrm{H} 2 \mathrm{O}-\mathrm{NaCl}-\mathrm{CaCl} 2$ fluid inclusions based on microthermometric and microanalytical data.- Geochimica et Cosmochimica Acta, 75/1, 21-40. doi:10.1016j.gca.2010.10.002

WHITNEY, D.L. \& EVANS, B.W. (2010): Abbreviations for names of rock-forming minerals.-American Mineralogist.., 95, 185-187. doi: 10.2138/am.2010.3371

WILKINSON, J.J. \& EYRE, S.L. (2005): Ore-Forming Processes in Irish-Type Carbonate-hosted $\mathrm{Zn}-\mathrm{Pb}$ Deposits: Evidence from Mineralogy, Chemistry, and Isotopic Composition of Sulphides at the Lisheen Mine.- Economic Geology, 100, 63-86.

WILKINSON, J.J. (2001): Fluid inclusion in hydrothermal ore deposits.- Lithos., 55, 229-272. doi: 10.1016/S0024-4937(00)00047-5

WILKINSON, J.J. \& HITZMAN, M.W. (2015): The Irish Zn-Pb Orefield: The view from 2014.- In: Current Perspectives in Zinc Deposits. Irish association for economic geology, Geological survey of Ireland., 59-69.

YAGHOOBPOUR, M. (2004): Investigation of geochemical, Isotopic and fluid inclusion related to the source $\mathrm{Pb}-\mathrm{Zn}$ ore deposit in Duna.- M. Sc, Tehran-Shomal University.

ZANCHI, A., ZANCHETTA, S., GARZANTI, E., BALINI, M., BERRA, F., MATTEI, M. \& MUTTONI, G. (2009): The Cimmerian evolution of the Nakhlak-Anarak area, Central Iran and its bearing for the reconstruction of the history of the Eurasian margin.- In: BRUNET, M. F., WILMSEN, M., GRANATH, J.W. (eds.): South Caspian to Central Iran basins. Geological Society, London, Special Publications, 312, 261-286. doi:10.1144/SP312.1

ZARTMAN, R.E. \& DOE, B.R. (1981): Plombotectonics, The model.- Tectonophysics, 75/1-2, 135-162. doi:10.1016/0040-1951(81)90213-4 